\title{
Access to 4-Year Public Colleges and Degree Completion
}

\section{Citation}

Goodman, Joshua, Michael Hurwitz, and Jonathan Smith. 2017. "Access to 4-Year Public Colleges and Degree Completion." Journal of Labor Economics 35 (3) (July): 829-867. doi:10.1086/690818.

\section{Permanent link}

http://nrs.harvard.edu/urn-3:HUL.InstRepos:34298861

\section{Terms of Use}

This article was downloaded from Harvard University's DASH repository, and is made available under the terms and conditions applicable to Other Posted Material, as set forth at http:// nrs.harvard.edu/urn-3:HUL.InstRepos:dash.current.terms-of-use\#LAA

\section{Share Your Story}

The Harvard community has made this article openly available.

Please share how this access benefits you. Submit a story.

Accessibility 


\title{
Access to 4-Year Public Colleges and Degree Completion
}

\author{
Joshua Goodman, Harvard University \\ Michael Hurwitz, College Board \\ Jonathan Smith, College Board
}

\begin{abstract}
Does access to 4-year colleges affect degree completion for students who would otherwise attend 2-year colleges? Admission to Georgia's 4-year public sector requires minimum SAT scores. Regression discontinuity estimates show that access to this sector increases 4-year college enrollment and college quality, largely by diverting students from 2-year colleges. Access substantially increases bachelor's degree completion rates for these relatively low-skilled students. SATretaking behavior suggests students value access to 4-year public colleges, though perhaps less than they should. Our results imply that absolute college quality matters more than match quality, and they suggest potential unintended consequences of free community college proposals.
\end{abstract}

\section{Introduction}

A 2014 White House summit on college access reported: "Too few lowincome students apply to and attend colleges and universities that are the best fit for them, resulting in a high level of academic undermatch. . . .

This research reflects the views of the authors and not their corresponding institutions. For helpful comments, we thank Kehinde Ajayi, Chris Avery, Raj Chetty, Damon Clark, Gordon Dahl, David Deming, Yingying Dong, Maria Fitzpatrick, Jessica Howell, Joshua Hyman, Larry Katz, and Martin West, as well as conference and seminar participants at Harvard University, University of California, San Diego,

[Journal of Labor Economics, 2017, vol. 35, no. 3]

(C) 2017 by The University of Chicago. All rights reserved. 0734-306X/2017/3503-0005\$10.00

Submitted April 24, 2015; Accepted June 8, 2016; Electronically published March 29, 2017 
Students who attend selective institutions, which tend to have more resources available for student support, have better education outcomes, even after controlling for student ability" (White House 2014). We have clear evidence that students, particularly low-income ones, do not attend the highest quality colleges available to them (Bowen, Chingos, and McPherson 2009; Dillon and Smith 2013; Hoxby and Avery 2013; Smith, Pender, and Howell 2013) and that initial college choices can be altered by relatively low-cost interventions (Bettinger et al. 2012; Carrell and Sacerdote 2013; Hoxby and Turner 2013; Castleman, Page, and Schooley 2014; Pallais 2015; Smith, Hurwitz, and Howell 2015). Less clear is the extent to which changing such college choices affects students' longer-run outcomes, such as degree completion and labor market earnings.

Whether the type and quality of college chosen affects such outcomes bears directly on a number of economic and policy questions. These include the extent to which postsecondary institutional factors explain dropping college completion rates among US college enrollers (Belley and Lochner 2007; Bound, Lovenheim, and Turner 2010; Bailey and Dynarski 2011); the relative importance of "match" quality versus absolute quality (Dillon and Smith 2013) and how that, in turn, informs debates about affirmative action (Arcidiacono and Lovenheim 2016); the extent to which informational interventions like the College Scorecard website can improve student outcomes by changing college choices (Hurwitz and Smith 2016); and, finally, what impact recent proposals to make community college free will have on students choosing between that sector and other options.

Identifying the impact of college choice on longer-run outcomes requires separating student-level factors, such as academic skill and financial resources, from college-level factors, such as funding levels or operational efficiency. The nonrandom selection of students into colleges of different types and qualities generally confounds attempts to do so. The major empirical challenge is thus to find an exogenous source of variation in college choice. We do so by exploiting minimum test score thresholds used during the college admissions process. Such thresholds are used by one in five US colleges (Briggs 2009) and by many states' public college systems, including California, Florida, and Texas, though often in combination with high school grade point average (GPA).

University of California, Irvine, the National Bureau of Economic Research, the Society of Labor Economists, the Society for Research on Educational Effectiveness, the Association for Education Finance and Policy, the Southern Economic Association, and the College Board. Shelby Lin and Carlos Paez provided excellent research assistance. Joshua Goodman gratefully acknowledges support from the Taubman Center for State and Local Government. All errors are our own. Contact the corresponding author, Joshua Goodman, at joshua_goodman@hks.harvard.edu. Information concerning access to the data used in this article is available as supplementary material online. 
We focus on the Georgia State University System (GSUS), which publicly announces minimum SAT scores that are required for first-year admission, irrespective of high school GPA. Such thresholds play an important role in access to the state's public 4-year college sector. Regression discontinuity estimates around these minimum thresholds show that access to the 4-year public sector increases both the probability of enrollment in any 4-year college and the quality of college chosen, largely by diverting students from 2-year colleges. Most important, access substantially increases bachelor's degree completion rates for these relatively low-skilled students. Missing these thresholds increases SAT-retaking rates, suggesting that students value access to the 4-year public sector, though perhaps less than the completion benefits suggest they should.

Our work contributes in three ways to existing literature on the impacts of college choice. First, this is the only research in the United States context to document the impact of test score-based access to an entire college sector. Our results are driven by one state's set of 4-year public colleges, not the potentially idiosyncratic effect of a single college. In this sense, our work resembles recent research exploiting Colombian and Chilean national systems of college admissions thresholds to estimate the impact of college quality and sector on a variety of labor market and other outcomes (Saavedra 2008; Hastings, Neilson, and Zimmerman 2013; Kaufmann, Messner, and Solis 2013).

Our second contribution is to cleanly identify college choice impacts for relatively low-skilled students choosing largely between 2- and 4-year colleges. Much of the literature estimating the impact of college choice on graduation rates and earnings focuses on higher-skilled students exposed to quality differences within the 4-year sector, including the Latin American studies cited earlier, and US studies based on selection on observables models (Black and Smith 2004, 2006; Black, Smith, and Daniel 2005; Long 2008; Dale and Krueger 2014), twin fixed effects models (Smith 2013), and regression discontinuity designs (Hoekstra 2009; Cohodes and Goodman 2014). Our focus on low-skilled students supplements evidence that college quality matters for high-skilled students.

Our results are also consistent with previous evidence of a graduation rate penalty associated with choosing a 2-year college instead of a 4-year college (Rouse 1995, 1998; Leigh and Gill 2003; Long and Kurlaender 2009; Reynolds 2012; Smith and Stange 2015). Such a penalty may stem from the substantial differences across these two sectors along multiple dimensions, including peer quality, faculty quantity and quality, and funding levels more generally, which affect the quantity and quality of academic resources available to students. Our work is closest in spirit to Zimmerman (2014), in which relatively low-skilled students who would otherwise attend community colleges see substantial labor market returns to access to the least selective 4-year public college in Florida. Our demonstration that college quality 
affects degree completion for such students may explain part of the labor market return observed in that and other contexts. ${ }^{1}$

Our third contribution is to connect test-retaking behavior to demand for access to a particular set of colleges, in this case the public 4-year sector. Prior research on SAT-taking behavior has shown increased retaking to achieve round-numbered scores (Pope and Simonsohn 2011) or to increase maximum scores (Vigdor and Clotfelter 2003), which are an important factor in an increasingly competitive admissions process (Bound, Hershbein, and Long 2009). Jepsen, Mueser, and Troske (2016) also find substantial retaking of certification exams in order to earn a GED. We document increased rates of test-retaking in response to failing to meet publicly known college admissions thresholds. These thresholds have no significance outside of the GSUS admissions process. Increased retaking rates thus indicate that students value access to the 4-year public sector, perhaps in part because they perceive the degree completion benefits such access brings. This is the first paper we are aware of to document SAT-retaking as evidence of demand for a particular college sector.

The structure of the remainder of the paper is as follows. Section II describes the data, the context studied here, and our regression discontinuity methodology. Section III presents summary statistics and evidence on the strength of our first stage and the validity of our empirical design. Section IV describes our enrollment and completion results. Section V discusses the broader implications of our results.

\section{Data, Context, and Empirical Strategy}

\section{A. Data}

We use student-level data for the graduating high school classes of 2004-8, which are collected from two sources. The first data set, collected and maintained by the College Board (CB), contains information on the nearly 1.5 million students in each high school graduation cohort who take the SAT at least once. The SAT is a test many 4-year colleges require for admission. It contains a math section and a critical reading section, each of which is scored in increments of 10 on a scale between 200 and $800 .^{2}$ Students may retake the SAT as often as the testing schedule permits, with each test administration costing roughly $\$ 40$ during the time period studied here. Fee waivers are available to low-income students taking the exam for the first or second time.

The CB data contain all scores students ever receive across multiple test takes, as well as the dates of those takes, allowing us to identify both first and maximum SAT scores. College admissions offices frequently rely on

\footnotetext{
${ }^{1}$ Canaan and Mouganie (forthcoming) also find labor market returns attributable to college quality for relatively low-skilled French students.

${ }^{2}$ A third section on writing does not play a role in the thresholds studied here.
} 
students' maximum scores, defined as the sum of their maximum math and critical reading scores regardless of whether they were earned on the same test date. Although we use this maximum score for some analyses, we focus largely on students' first SAT scores to avoid potentially endogenous retaking behavior. The CB data identify colleges to which students send their SAT scores, which serve as good proxies for actual college applications (Card and Krueger 2005; Pallais 2015). The data also contain self-reported information on student race, gender, parental income and education, and high school attended. Self-reported year of high school graduation is used to assign students to graduating classes.

These data are then merged with data from the National Student Clearinghouse (NSC), which collects information on the vast majority of students enrolled in US postsecondary institutions. In the years studied here, the NSC captured somewhere between $90 \%$ and $95 \%$ of all Georgia students enrolled in Title IV institutions, according to Dynarski, Hemelt, and Hyman (2015). ${ }^{3}$ Data from the NSC allow us to track a student's postsecondary trajectory, including initial enrollment and ultimate degree completion. We focus on the 2004-8 high school graduation classes for whom we can observe 6-year college graduation rates.

Measuring college quality across the 2- and 4-year sectors is difficult because traditional data sources, such as the Integrated Postsecondary Education Data System (IPEDS), lack comparable measures between the two sectors. IPEDS contains average SAT scores of incoming students at 4-year colleges but does not have any similar measure for 2-year colleges, which generally do not require students to have taken the SAT. IPEDS is also limited by the fact that degree completion rates reported by colleges do not account for the outcomes of transfer students, a particularly acute problem for the 2-year sector, which is designed in part to facilitate transfers to the 4-year sector.

We therefore use the merged CB and NSC data to construct measures of college quality that are comparable across these sectors. To measure student quality, we follow Smith and Stange (2015) and assign each college the average score of that college's first-time students on the PSAT, a College Board test taken by high school sophomores and juniors, including many who do not later take the SAT. We standardize PSAT scores by cohort to have mean zero and standard deviation one. We thus assign each student a standardized measure of the quality of peers to whom he/she is exposed at his/her initial college. For students who do not initially enroll in college within 1 year of graduating from high school, we assign a value of -0.54 standard deviations, which represents the average standardized PSAT score for all such students.

${ }^{3}$ See table 2, where the enrollment coverage rate for Georgia ranges from $89.9 \%$ in 2005 to $94.8 \%$ in 2011 . Other mid-Atlantic and Southeast states look similar. Some of those not captured by NSC may be enrolling in for-profit institutions. 
To measure institutional degree completion rates, we identify all SATtakers who enroll in that college and then compute the fraction of such students who complete a bachelor's degree from any institution within 6 years. This measure has the advantage of being computable for both the 2- and 4-year sectors, as well as including transfer students among those degree recipients. For students who do not initially enroll in college within 1 year of graduating from high school, we assign a value of $6.7 \%$, which represents the average 6-year bachelor's degree completion rate for all such students.

\section{B. Georgia Context}

The main analytic sample consists of all students who resided in the state of Georgia at the time they took the SAT. Georgia's Board of Regents requires that SAT-takers score at least 430 in critical reading and at least 400 in math in order to be admitted to universities within the Georgia State University System. The set of 184 -year universities governed by this requirement consists of three research universities, two regional universities, and 13 state universities (see table A1). Five of the 18 universities impose higher minimum thresholds than required by the Board of Regents, though only two impose substantially higher thresholds. Georgia's state and technical colleges, all of which are primarily 2 -year institutions, impose much lower minimum thresholds.

The Georgia context is interesting for three reasons. First, these thresholds apply to all students considering 4-year public institutions in Georgia. As we show later, over $60 \%$ of Georgia students near these thresholds who enroll in 4-year colleges do so in these GSUS institutions. These thresholds thus affect the majority of college options for students in this market. Second, the GSUS minimum admissions thresholds correspond to roughly the 25 th percentile of the distribution of scores among Georgia SAT-takers in the years in question. The marginal student here has relatively low academic skills and is often choosing between 2- and 4-year colleges. Third, the public nature of these requirements means that students can, in theory, take the thresholds into account when planning their college application process. We explore whether students do, in fact, plan around these thresholds.

\section{Empirical Strategy}

To eliminate selection bias driven by different types of students making different college choices, we exploit the thresholds previously described. We use a regression discontinuity design to compare a variety of outcomes between students just above and just below these thresholds. We generate first-stage estimates through local linear regressions of the form:

$$
\begin{aligned}
\text { GSUS }_{i c}= & \alpha_{0}+\alpha_{1} \text { Access }_{i c}+\alpha_{2} \text { Distance }_{i c} \\
& +\alpha_{3}\left(\text { Access }_{i c} \times \text { Distance }_{i c}\right)+\gamma_{c}+\mu_{i c} .
\end{aligned}
$$


Here, GSUS indicates the initial enrollment of student $i$ in high school class $c$ in a Georgia 4-year public college within 1 year of high school graduation. Access is an indicator for meeting or exceeding the relevant test score threshold, and Distance measures the number of SAT points each student's score is from the threshold. We control flexibly for time-varying shocks by including high school class fixed effects $\left(\gamma_{c}\right)$. Because the two sets of students on either side of the threshold are nearly identical in terms of academic skill and other characteristics, the coefficient of interest, $\alpha_{1}$, estimates the causal effect of satisfying the SAT admissions requirements on enrollment in Georgia's 4-year public sector.

We estimate the impact of access on outcomes through reduced form regressions of the form:

$$
\begin{aligned}
Y_{i c}= & \rho_{0}+\rho_{1} \text { Access }_{i c}+\rho_{2} \text { Distance }_{i c} \\
& \left.+\rho_{3} \text { Access }_{i c} \times \text { Distance }_{i c}\right)+\sigma_{c}+\nu_{i c} .
\end{aligned}
$$

We consider three different sets of outcomes $Y$. The first are measures of enrollment in other college sectors, in order to estimate which types of colleges students are forgoing when enrolling in the 4-year public sector. The second are the measures of college quality mentioned previously, namely student quality and institutional completion rates, in order to estimate how enrollment in the 4-year public sector changes the quality of one's initial college. The third are various measures of students' degree completion, in order to estimate the impact of initial college choice on completion rates.

We also generate instrumental variable estimates of the form:

$$
\begin{aligned}
Y_{i c}= & \beta_{0}+\beta_{1} \text { GSUS }_{i c}+\beta_{2} \text { Distance }_{i c} \\
& +\beta_{3}\left(\text { Access }_{i c} \times \text { Distance }_{i c}\right)+\delta_{c}+\varepsilon_{i c},
\end{aligned}
$$

where GSUS is instrumented by access according to equation (1). The coefficient of interest, $\beta_{1}$, estimates the impact of enrollment in the 4-year public sector on the outcomes mentioned above. Using GSUS as the endogenous regressor allows us to capture the full set of marginal students whose enrollment decisions were altered by the thresholds. ${ }^{4}$ This implies that we are estimating the impact of enrollment in the 4-year public sector relative to the full set of forgone alternatives, including enrollment in 2-year colleges, in non-GSUS 4-year colleges, and in no college at all.

In Georgia, a student must score at least 430 in reading and at least 400 in math. We therefore define distance from the threshold as

${ }^{4}$ Using 4-year college enrollment as the endogenous variable, for example, would yield estimates that failed to account for the empirically important fact that the thresholds shift some students between private and public 4-year colleges. 


$$
\text { Distance }=\min \left(\mathrm{SAT}_{\mathrm{R}}-430, \mathrm{SAT}_{\mathrm{M}}-400\right) \text {. }
$$

This minimum function collapses the two-dimensional threshold into a single dimension, where negative values imply that a student has missed at least one threshold and zero or positive values imply that a student has met or exceeded both thresholds. This method of collapsing a multi-dimensional boundary into a single dimension is discussed in Reardon and Robinson (2012) and has previously been used in papers such as Goodman (2008) and Papay, Murnane, and Willett (2014). We show that our estimates are quite similar if we instead define the running variable as distance to just the math threshold or to just the verbal threshold.

Because Georgia's admissions thresholds are publicly known, we define each student's distance from the threshold using that student's first SAT scores. This is similar to the approach used by Jepsen et al. (2016), who evaluate the labor market return to earning a GED. First scores do not suffer from potential endogeneity driven by any retaking of the SAT in reaction to scoring below the thresholds. We will provide evidence that, though there is endogenous retaking of SAT in reaction to the thresholds, the magnitude of that endogeneity is quite small. Using maximum scores to define the running variable yields estimates generally similar in magnitude but more precise than those generated by first scores. This increased precision comes from the stronger first-stage relationship between maximum scores and enrollment because maximum scores are the ones considered during the admissions process.

We run the local linear regressions above using bandwidths of 60 SAT points, which corresponds closely to the optimal bandwidths suggested by Imbens and Kalyanaraman (2012) to balance precision against minimization of bias due to nonlinearities far from the threshold. Such optimal bandwidths vary by outcome, so fixing the bandwidth across regressions has the advantage of defining a single sample clearly. We show that our estimates are not sensitive to this bandwidth choice. We cluster standard errors by discrete distance to the threshold, as suggested by Lee and Card (2008). Clustering instead by high school yields very similar standard errors.

\section{Summary Statistics and Validity of the Research Design}

\section{A. Summary Statistics}

Table 1 presents summary statistics for Georgia residents from the high school classes of 2004-8. As seen in column 1, this sample is $60 \%$ white and $26 \%$ black. Nearly one-third of students are low-income, defined here as reporting annual family income of less than $\$ 60,000 .^{5}$ The average student

\footnotetext{
${ }^{5}$ The remaining two-thirds of students are roughly evenly split between those reporting income over $\$ 60,000$ and those not reporting income.
} 


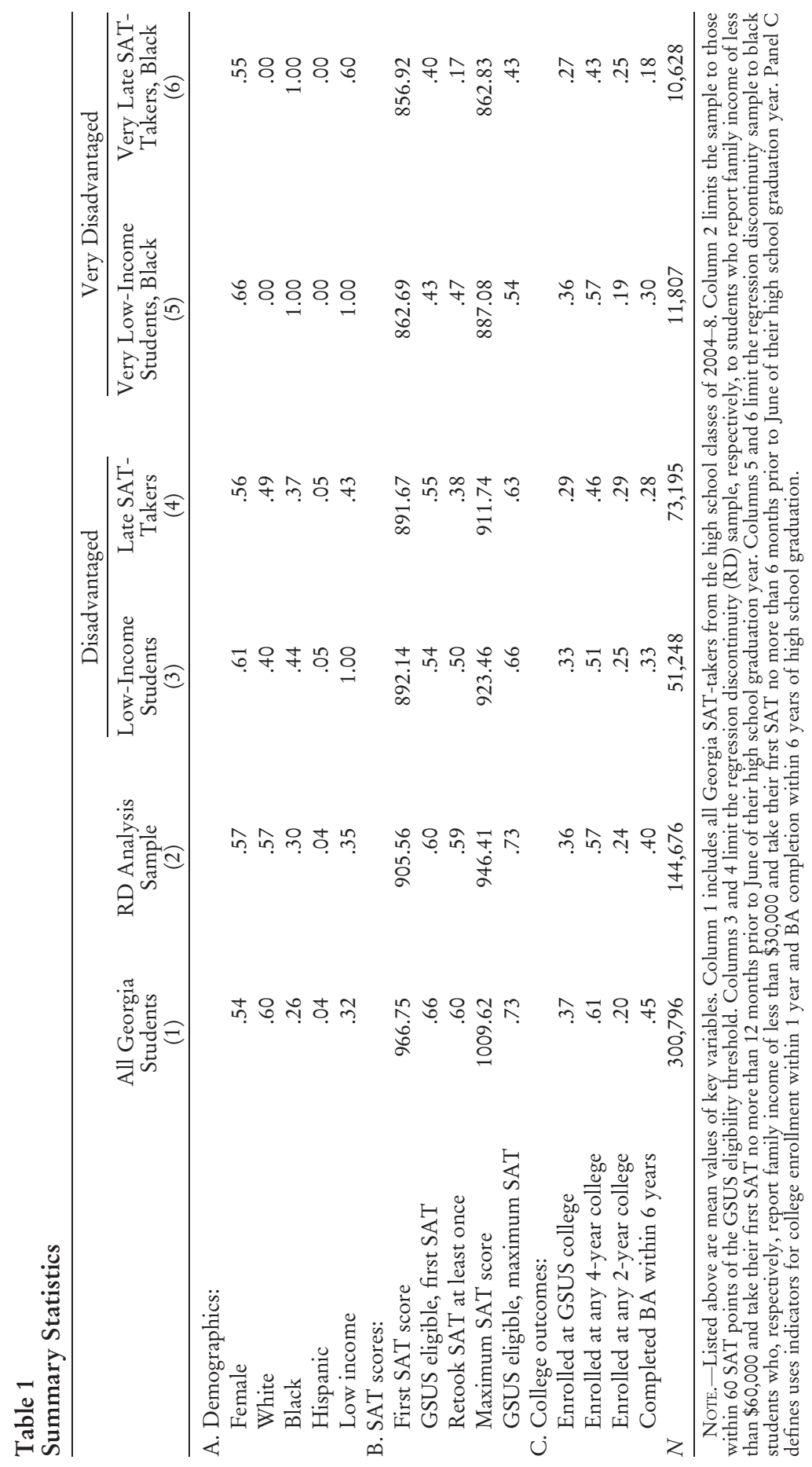

This content downloaded from 128.103.193.204 on April 03, 2017 14:20:35 PM All use subject to University of Chicago Press Terms and Conditions (http://www.journals.uchicago.edu/t-and-c). 
in this sample has a first SAT score of 967, and two-thirds have first SAT scores sufficiently high to satisfy the GSUS minimum thresholds. The marginal student studied here is thus at the 34th percentile of the skill distribution of Georgia SAT-takers. Most students retake the SAT at least once, so $73 \%$ ultimately meet the GSUS thresholds. Further, 37\% first enroll in a GSUS college within 1 year of graduating from high school, while $61 \%$ enroll in any 4-year college. This implies that three-fifths of students who enroll in a 4-year college do so in the in-state public sector. Another $20 \%$ first enroll in a 2-year college. Only $45 \%$ complete a bachelor's degree within 6 years of graduating from high school.

Our main regression discontinuity sample, shown in column 2, includes those students whose first SAT scores fell within 60 points of the GSUS eligibility threshold. Compared to the overall Georgia sample, these students are slightly more likely to be black, to be from low-income families, and to score 60 points lower on the SAT, and they are less likely to complete a bachelor's degree. We also focus on subgroups of students whose initial college choices are particularly likely to be affected by differences in SATbased access to the 4-year public sector. Such students may lack the resources or information to make application and test-retaking decisions that would otherwise limit the extent to which such thresholds constrain their college options.

We use income and SAT-taking dates as two ways to identify subgroups who are likely "disadvantaged" along these dimensions. Low-income students, who report family income less than $\$ 60,000$ and who comprise onethird of the RD sample, are likely constrained financially and along other dimensions. ${ }^{6}$ Late SAT-takers, who first take the SAT no more than 12 months prior to high school graduation and who comprise one-half of the RD sample, are likely less knowledgeable about the college application process generally and about the value of having time to retake the SAT. Given the particular challenges faced by African Americans in the Georgia context, we also use the intersection of race, income, and SAT timing to identify two subgroups of students whom we refer to as "very disadvantaged." One such group comprises black students from families earning less than $\$ 30,000$ annually. The other group is black students who first take the SAT no more than 6 months prior to high school graduation. We focus on such disadvantaged students both because they are inherently of interest and because they show particularly strong first-stage impacts of the GSUS thresholds on college enrollment. None of our central findings are sensitive to the precise choices that define these groups.

\footnotetext{
${ }^{6}$ Because one-third of the sample does not report income, this threshold identifies the bottom half of the income-reporting distribution. None of our results are sensitive to choosing a lower income threshold to define "low income."
} 


\section{B. Validity of the Research Design}

We perform two checks that our regression discontinuity design satisfies the key assumption that students on either side of the threshold are similar in terms of observed and unobserved characteristics. First, following McCrary (2008), we check for smoothness in the density of observations, the violation of which could suggest that students can at least partially control which side of the threshold they fall on. ${ }^{7}$ In the Georgia sample, the density of observations is nearly identical just below and just at the threshold. This suggests that students cannot manipulate their first SAT scores, an unsurprising result given that SATs are centrally scored and students do not know precisely how scaled scores are generated.

Second, we test for balance in observed covariates across the threshold for the entire sample as well as for our disadvantaged and very disadvantaged subsamples (see appendix table A2). Consistent with students' inability to precisely manipulate which side of the threshold they initially fall on, we see little indication of imbalance in observed covariates such as income, parental education, race, and gender. The few observed differences are small in magnitude, and the number is consistent with the rate of false positives expected given the number of tests being performed. We perform joint tests of imbalance by generating predicted 4-year college enrollment and bachelor's degree completion rates, based on students' gender, race, income, and parental education. What little evidence we observe of imbalance in predicted outcomes is very small in magnitude and opposite in sign to our subsequent results, again suggesting that our main findings are not generated by imbalance in student types across the threshold. Graphical versions of these balance tests for income and predicted degree completion show no visually apparent discontinuities (see appendix figure A2). We show in later robustness checks that controlling for all observed covariates does not meaningfully change our point estimates, providing further evidence that students on either side of the threshold are practically identical.

\section{College Enrollment and Completion Effects}

\section{A. First Stage}

We now show that the GSUS minimum admissions thresholds generate exogenous variation in the probability that a student enrolls in a GSUS col-

\footnotetext{
${ }^{7}$ See appendix figure A1, which graphs the density of SAT-takers as a function of distance of first SAT scores from the admissions threshold. The closed circles represent our Georgia sample, and the open circles represent SAT-takers from all other states during this time period. The density of observations has a local peak 10 points above the threshold due to the fact that certain scaled scores were more common translations of raw scores during this time period. That this peak appears off the threshold and appears in the non-Georgia sample as well suggests that it is unrelated to the GSUS eligibility criteria and thus poses no threat to validity here.
} 
lege. Figure 1 shows graphically the relationship between distance to the threshold and the probability of enrolling in one of Georgia's 4-year public colleges. Panel $A$, which defines distance using maximum SAT scores, shows a clear and large discontinuity, with students just above the threshold substantially more likely to enroll in the 4-year public sector than those just below it. GSUS enrollment below the threshold is nonzero for two reasons. First, students can also gain admission through the ACT exam, the SAT's primary alternative, taken by roughly $30 \%$ of Georgia's high school classes of 2004-8. Second, each institution may exempt individual students from these minimum thresholds if such students otherwise demonstrate potential for success through interviews, portfolios, or life experiences.

Because the maximum SAT score is potentially endogenous, we present this graphical evidence only to show that GSUS colleges clearly use the SAT thresholds as part of the admissions process. Our first stage will be generated instead by variations on panel $B$, which defines distance using first SAT scores. This graph also shows a discontinuity, albeit one much smaller than in panel $A$ because GSUS colleges use maximum, and not first, SAT scores in the admissions process. Panel A of table 2 confirms the existence of a small but clear discontinuity, showing regression estimates of the first-stage impact of SAT-based access on enrollment in Georgia's 4-year public colleges. For the sample of all students, meeting the GSUS thresholds increases the probability of GSUS enrollment by 2-3 percentage points. These estimates are relatively stable over a variety of bandwidths and are always highly statistically significant, so access easily passes traditional tests for being a strong instrument.

Panel B of table 2 shows little evidence that SAT thresholds affect college enrollment choices of "advantaged" students, those whose families earn over $\$ 60,000$ or those who take their first SAT more than 12 months prior to high school graduation. Admissions thresholds instead affect disadvantaged students, for whom initial eligibility increases enrollment in GSUS colleges by about 4 percentage points, from a base enrollment rate of about $35-40$ percentage points. Initial eligibility increases GSUS enrollment by an even larger 78 percentage points for very disadvantaged students, from a base of 26 percentage points. All of these first-stage estimates are highly statistically significant, and eligibility easily qualifies as a strong instrument in each of these disadvantaged subsamples. Figure 2 shows graphical versions of these disadvantaged subsamples' first stages. All four panels show visually obvious discontinuities in GSUS enrollment rates at the threshold and nowhere else.

SAT-based eligibility for admission to in-state 4-year public colleges substantially and clearly affects the initial college enrollment choices of disadvantaged students and even more so for students who are more disadvantaged. Students from relatively high-income families and who are knowledgeable enough about the admissions process to take the SAT prior to senior year are unaffected by the GSUS thresholds in part, as we show later, because they 

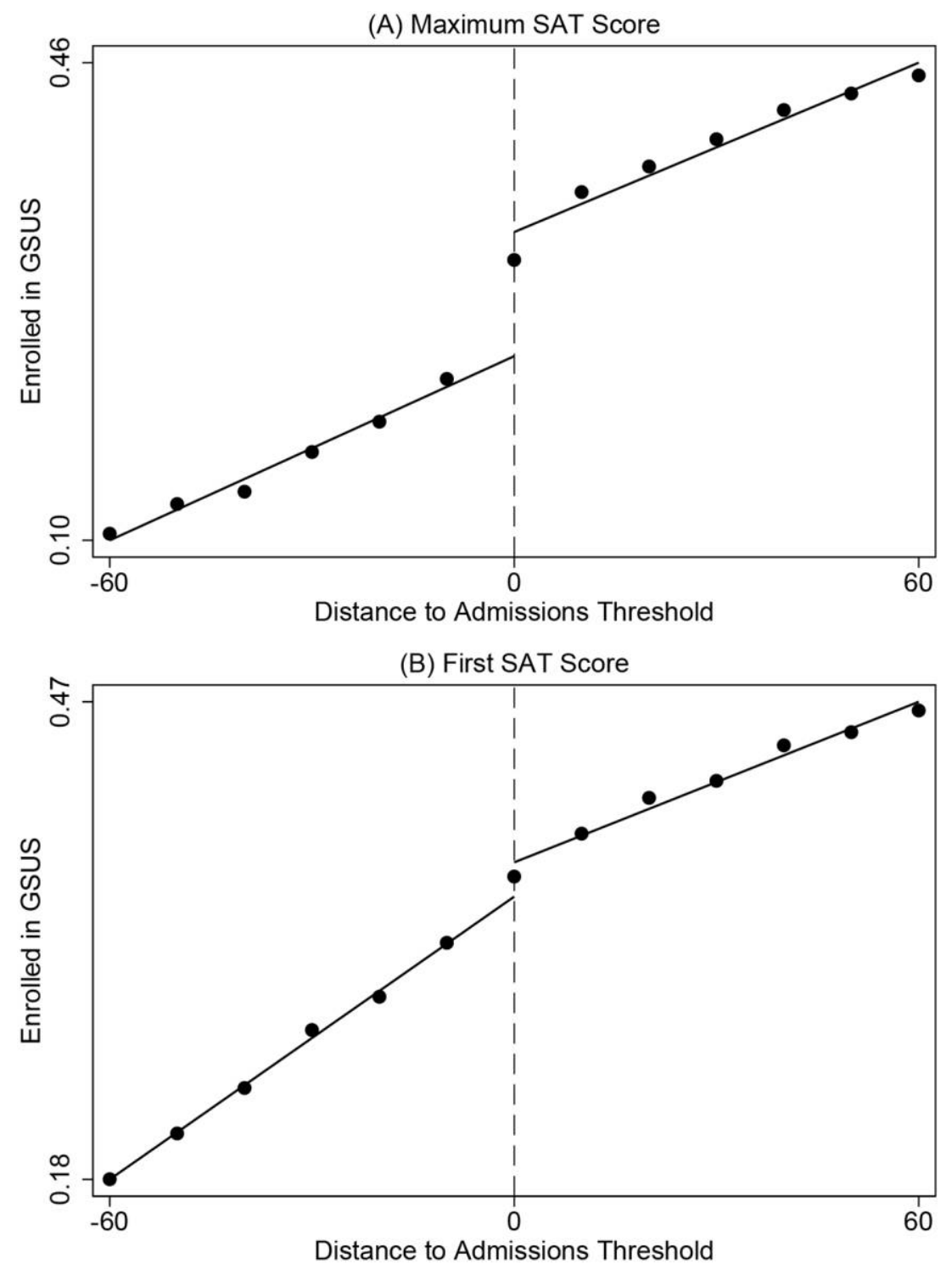

FIG. 1.-First stage. Panel $A$ shows the fraction of students enrolling at in-state public 4-year colleges within 1 year of high school graduation, as a function of the distance of students' maximum SAT scores from the GSUS eligibility threshold. Panel $B$ shows enrollment rates by the distance of students' first SAT scores from the threshold. The sample comprises Georgia's 2004-8 high school classes. Also shown are fitted regression lines from the baseline specification using a bandwidth of 60 points. 
Table 2

First-Stage Impact of Eligibility on GSUS Enrollment

\begin{tabular}{|c|c|c|c|c|c|}
\hline & $\begin{array}{l}\mathrm{BW}=40 \\
(1)\end{array}$ & $\begin{array}{l}\mathrm{BW}=50 \\
(2)\end{array}$ & $\begin{array}{l}\mathrm{BW}=60 \\
(3)\end{array}$ & $\begin{array}{l}\mathrm{BW}=70 \\
(4)\end{array}$ & $\begin{array}{c}\mathrm{BW}=80 \\
(5)\end{array}$ \\
\hline \multicolumn{6}{|l|}{ A. All students: } \\
\hline \multicolumn{6}{|l|}{ All $($ control mean $=.33$} \\
\hline \multirow[t]{2}{*}{$\mathrm{IK}=40)$} & $.018 * * *$ & $.019 * * *$ & $.021 * * *$ & $.025 \% * *$ & $.032 * *$ \\
\hline & $(.004)$ & $(.004)$ & $(.005)$ & $(.005)$ & $(.007)$ \\
\hline \multicolumn{6}{|l|}{ B. Advantaged students: } \\
\hline \multicolumn{6}{|l|}{ Non-low income (control } \\
\hline \multirow[t]{2}{*}{ mean $=.36, \mathrm{IK}=50)$} & .009 & .006 & .007 & .013 & $.021 *$ \\
\hline & $(.013)$ & $(.011)$ & $(.011)$ & $(.011)$ & $(.012)$ \\
\hline \multicolumn{6}{|l|}{ Early SAT-taker (control } \\
\hline \multirow[t]{2}{*}{ mean $=.30, \mathrm{IK}=50)$} & .004 & .006 & .000 & .004 & .012 \\
\hline & $(.009)$ & $(.009)$ & $(.008)$ & $(.008)$ & $(.009)$ \\
\hline \multicolumn{6}{|l|}{$\begin{array}{l}\text { C. Disadvantaged students: } \\
\text { Low income (control }\end{array}$} \\
\hline Low income (control & & & & & \\
\hline & $.034 * * *$ & $.036 * * *$ & $.036 * * *$ & $.037 * * *$ & $.042 * * *$ \\
\hline & $(.006)$ & $(.006)$ & $(.007)$ & $(.006)$ & $(.006)$ \\
\hline \multicolumn{6}{|l|}{ Late SAT-taker (control } \\
\hline \multirow[t]{2}{*}{ mean $=.41, \mathrm{IK}=60)$} & $.036 * * *$ & $.037 * * *$ & $.044 * * *$ & $.045 * * \%$ & $.052 * * *$ \\
\hline & $(.006)$ & $(.005)$ & $(.007)$ & $(.006)$ & $(.007)$ \\
\hline \multicolumn{6}{|l|}{$\begin{array}{l}\text { D. Very disadvantaged students: } \\
\text { Very low income, black (control }\end{array}$} \\
\hline \multirow[t]{2}{*}{ mean $=.26, \mathrm{IK}=40)$} & $.074 * * *$ & $.067 * * *$ & $.070 * * *$ & $.066^{* * * *}$ & $.077 * * *$ \\
\hline & $(.012)$ & $(.014)$ & $(.014)$ & $(.013)$ & $(.013)$ \\
\hline \multirow{3}{*}{$\begin{array}{l}\text { Very late SAT-taker, black } \\
\quad(\text { control mean }=.26, \mathrm{IK}=60)\end{array}$} & & & & & \\
\hline & $.063 * * *$ & $.081 \% * \%$ & $.079 * * *$ & $.071 * * *$ & $.087 * * *$ \\
\hline & $(.012)$ & $(.010)$ & $(.009)$ & $(.011)$ & $(.014)$ \\
\hline
\end{tabular}

NoTE.-Each estimate comes from a local linear regression of an indicator for on-time enrollment in a GSUS college on an indicator for scoring at or above the GSUS threshold, using the listed bandwidth (BW) and controlling for high school class fixed effects. The sample comprises Georgia's 2004-8 graduating high school classes. Low-income and very low-income students are those reporting family income less than $\$ 60,000$ and $\$ 30,000$, respectively. Late and very late SAT-takers are those who, respectively, took their first SAT no more than 12 or 6 months prior to the June of their high school graduation year. Also listed are the Imbens-Kalyanaraman optimal bandwidth (IK; rounded to the nearest 10) and the mean rate of ontime GSUS enrollment for students 10 SAT points below the threshold. Heteroskedasticity robust standard errors clustered by distance to the admissions threshold are in parentheses.

$* p<.10$
$* * * 0$

are more likely to gain eligibility through subsequent retakes of the SAT. We therefore focus our analysis on the Georgia sample as a whole and the disadvantaged subsamples for whom eligibility most changes initial college enrollment.

\section{B. College Enrollment Effects}

To understand why GSUS enrollment might affect degree completion, we first estimate which alternative college options the marginal student forgoes in order to enroll in the 4-year public sector. Table 3 shows estimated impacts on the type and quality of the college chosen. Column 1 shows 


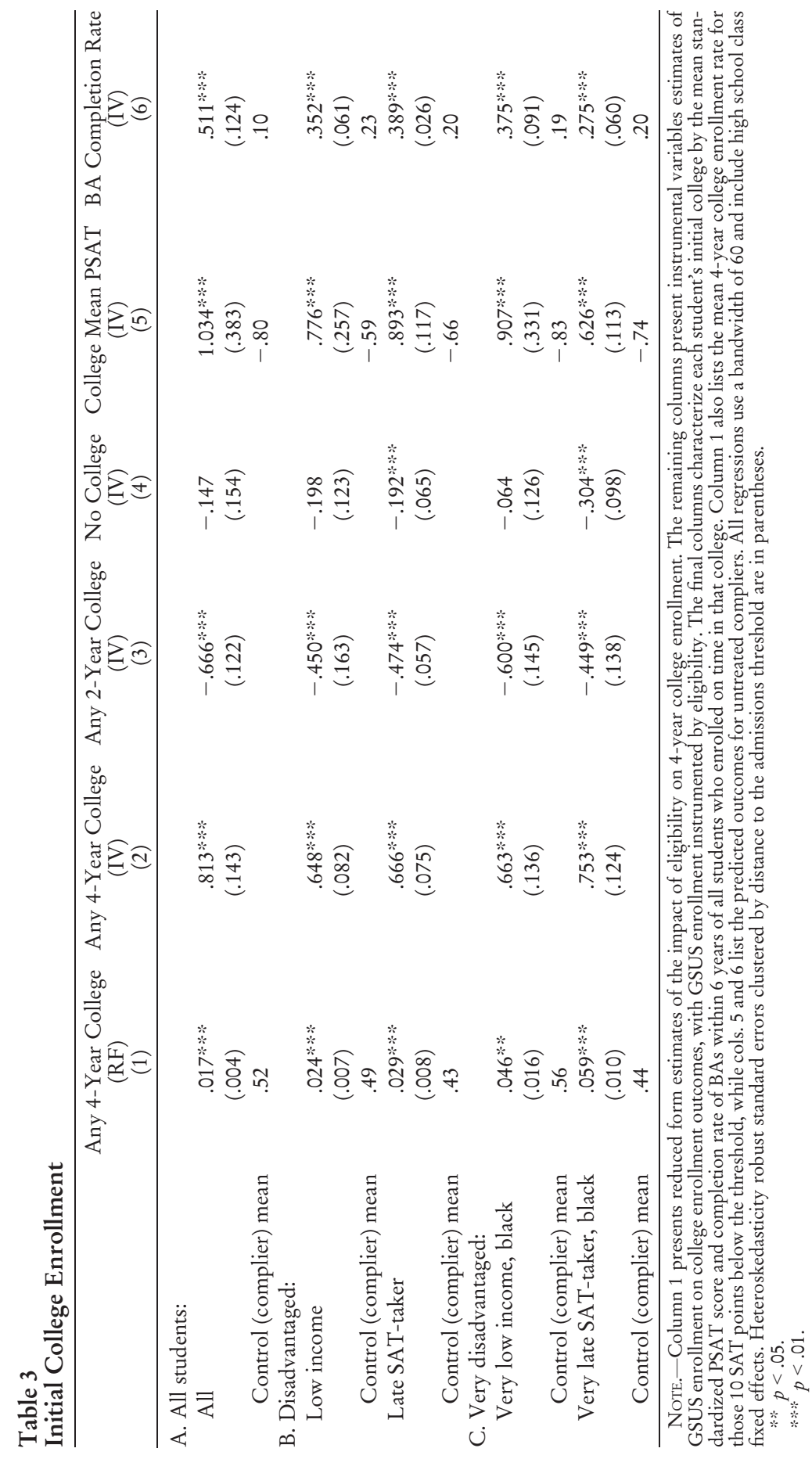

This content downloaded from 128.103.193.204 on April 03, 2017 14:20:35 PM 

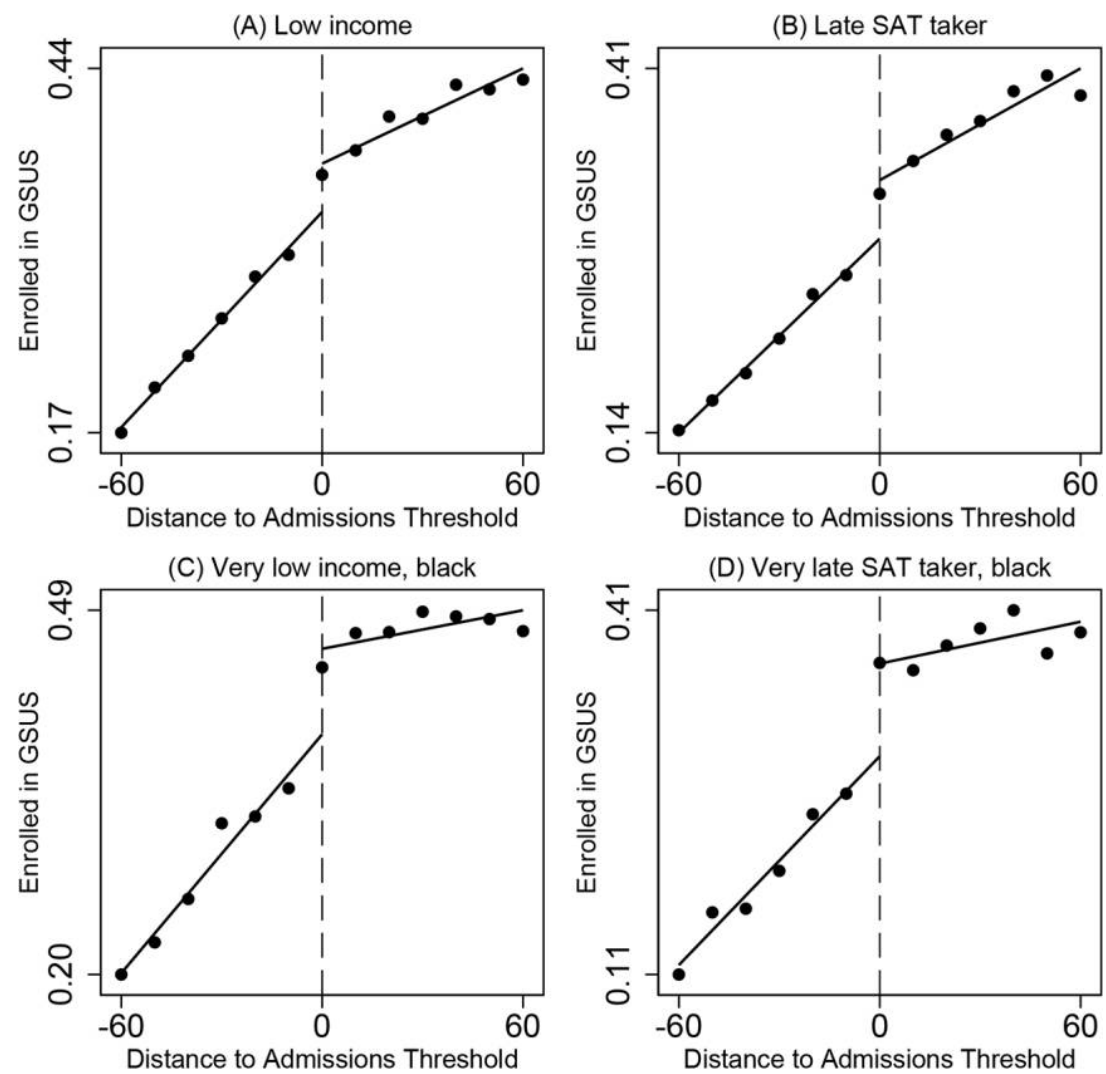

FIG. 2.-GSUS enrollment. Each panel shows the fraction of students enrolling at in-state public 4-year colleges within 1 year of high school graduation, as a function of the distance of students' first SAT scores from the GSUS eligibility threshold. Panel $A$ includes students who reported family incomes below $\$ 60,000$. Panel $B$ includes students who took their first SAT no more than 12 months prior to June of their high school graduation year. Panels $C$ and $D$ include black students who, respectively, reported family income of less than $\$ 30,000$ and who took their first SAT no more than 6 months prior to June of their high school graduation year. Also shown are fitted regression lines from the baseline specification using a bandwidth of 60 points.

reduced form estimates of the impact of eligibility on the probability of enrolling in any 4-year college. For the sample as a whole, eligibility increases 4-year college enrollment by 1.7 percentage points. Consistent with effects on GSUS enrollment, eligibility impacts on 4-year college enrollment are higher for disadvantaged students, around 2-3 percentage points, and even higher for very disadvantaged students, around 5-6 percentage points. These reduced form impacts can be seen graphically in figure 3, where each 

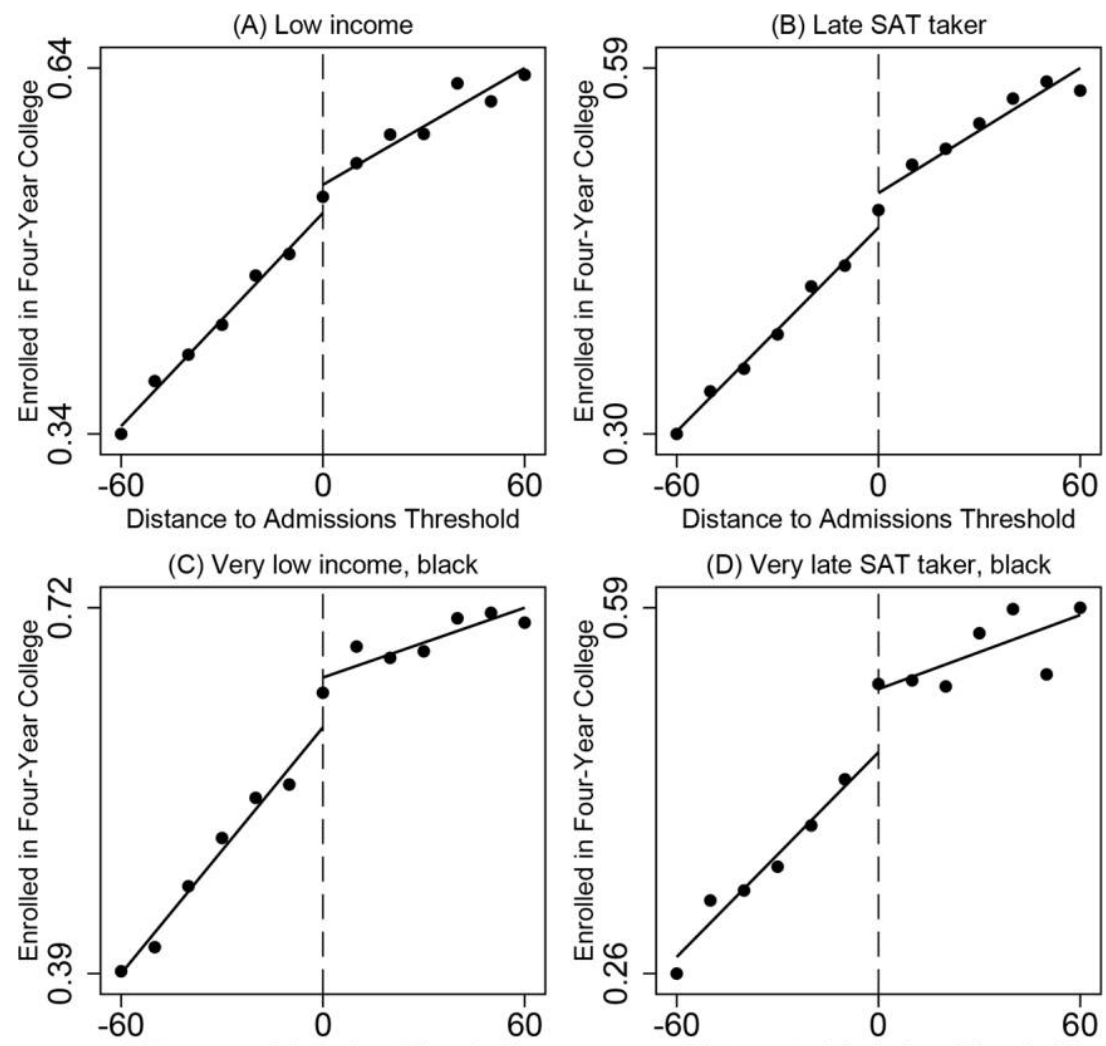

Distance to Admissions Threshold

Distance to Admissions Threshold

FIG. 3.-Four-year college enrollment. Each panel shows the fraction of students enrolling at any 4-year college within 1 year of high school graduation as a function of the distance of students' first SAT scores from the GSUS eligibility threshold. Panel $A$ includes students who reported family incomes below $\$ 60,000$. Panel $B$ includes students who took their first SAT no more than 12 months prior to June of their high school graduation year. Panels $C$ and $D$ include black students who, respectively, reported family income of less than $\$ 30,000$ and took their first SAT no more than 6 months prior to June of their high school graduation year. Also shown are fitted regression lines from the baseline specification using a bandwidth of 60 points.

disadvantaged subsample shows visually clear discontinuities in 4-year college enrollment at the GSUS eligibility threshold.

The remaining columns in table 3 present instrumental variables estimates of the impact of GSUS enrollment on the type and quality of college chosen. These estimates represent local average treatment effects for compliers, those students induced to enroll in GSUS because of their first SAT score-based eligibility. Column 2 suggests that, for the sample as a whole, enrolling in GSUS colleges increased by 81 percentage points the fraction enrolling in any 
4-year college. In other words, $81 \%$ of compliers would not have enrolled in a 4-year college if not for enrollment in the in-state 4-year public sector. Instead, $67 \%$ would have enrolled in a 2 -year college, another $15 \%$ would not have enrolled in any college, and the remaining 19\% would have enrolled in either an in-state private or out-of-state 4-year college.

Estimates for the disadvantaged subgroups tell a similar story. Twothirds to three-fourths of disadvantaged or very disadvantaged compliers would not otherwise have enrolled in a 4-year college, with roughly half instead choosing 2-year colleges and a smaller fraction not enrolling anywhere. Eligibility for admission to the 4-year public sector thus raises the rate of enrollment in 4-year colleges largely by attracting students who would otherwise have enrolled in 2-year colleges.

For the marginal student, enrollment in the 4-year public sector changes not only the sector of college chosen but also the quality of college chosen, as measured by peer quality and institutional graduation rates. Relative to the forgone alternatives that largely consist of 2-year colleges, enrollment in 4-year public colleges increases the quality of a student's peers by one standard deviation, or by 0.6-0.9 standard deviations for the disadvantaged subsamples. Control complier means, computed as suggested by Abadie, Angrist, and Imbens (2002) and Abadie (2003), imply that GSUS enrollment raises peer quality from well below average to slightly above average. GSUS enrollment increases by 51 percentage points the average bachelor's degree completion rate of compliers' initial colleges, or by 28-39 percentage points for the disadvantaged subsamples. The control complier means imply this effect represents more than a doubling of the graduation rate of the institution chosen. As a whole, these results make clear that 4-year public colleges in Georgia have substantially higher skilled students and higher degree completion rates than the alternatives the marginal student would otherwise have chosen. Access to the 4-year public sector thus increases both the overall rate of 4-year college enrollment and the quality of the college chosen. ${ }^{8}$

\section{College Completion Effects}

Our ultimate outcome of interest is the completion of a bachelor's degree from any institution within 6 years of high school graduation. The first two columns of table 4, respectively, show reduced form estimates of the impact of eligibility and instrumental variables estimates of the impact of GSUS enrollment on such completion rates. All such estimated impacts are large and

${ }^{8}$ Although not shown here, access to the 4-year public sector does not change the distance between a student's home and initial college. This suggests that proximity to college, or the probability of living at home while enrolled, does not explain the completion effects we document. 
Table 4

College Degree Completion

\begin{tabular}{|c|c|c|c|c|c|c|}
\hline & \multicolumn{3}{|c|}{ Completed BA within 6 Years } & \multicolumn{3}{|c|}{ Completed AA within 6 Years } \\
\hline & $\begin{array}{l}\text { (RF) } \\
(1)\end{array}$ & $\begin{array}{l}\text { (IV) } \\
\text { (2) }\end{array}$ & $\begin{array}{c}\text { (OLS) } \\
(3)\end{array}$ & $\begin{array}{c}(\mathrm{RF}) \\
(4)\end{array}$ & $\begin{array}{l}\text { (IV) } \\
(5)\end{array}$ & $\begin{array}{c}(\mathrm{OLS}) \\
(6)\end{array}$ \\
\hline \multicolumn{7}{|l|}{ A. All students: } \\
\hline All & $\begin{array}{l}.009 * * \\
(.003)\end{array}$ & $\begin{array}{l}.410 * * * \% \\
(.131)\end{array}$ & $\begin{array}{l}.257 \% * * \\
(.010)\end{array}$ & $\begin{array}{c}-.002 \\
(.003)\end{array}$ & $\begin{array}{c}-.084 \\
(.137)\end{array}$ & $\begin{array}{l}-.066 * * * \% \\
(.002)\end{array}$ \\
\hline Control (complier) mean & .37 & .19 & & .05 & .08 & \\
\hline \multicolumn{7}{|l|}{ B. Disadvantaged: } \\
\hline Low income & $\begin{array}{l}.015^{\% * \%} \\
(.004)\end{array}$ & $\begin{array}{l}.425 \% * * * \\
(.128)\end{array}$ & $\begin{array}{l}.275 * * * \% \\
(.007)\end{array}$ & $\begin{array}{l}.002 \\
(.005)\end{array}$ & $\begin{array}{c}.045 \\
(.131)\end{array}$ & $\begin{array}{l}-.076^{* * * \%} \\
(.002)\end{array}$ \\
\hline Control (complier) mean & .31 & .16 & & .06 & .00 & \\
\hline Late SAT-taker & $\begin{array}{l}.019 \% * * \% \\
(.004)\end{array}$ & $\begin{array}{l}.424 * \% * \% \\
(.061)\end{array}$ & $\begin{array}{l}.256^{* * * \%} \\
(.005)\end{array}$ & $\begin{array}{c}-.003 \\
(.003)\end{array}$ & $\begin{array}{c}-.078 \\
(.063)\end{array}$ & $\begin{array}{l}-.072^{* * * \%} \\
(.001)\end{array}$ \\
\hline Control (complier) mean & .26 & .11 & & .06 & .08 & \\
\hline \multicolumn{7}{|l|}{ C. Very disadvantaged: } \\
\hline Very low income, black & $\begin{array}{l}.020 \% \\
(.011)\end{array}$ & $\begin{array}{l}.289 * \\
(.154)\end{array}$ & $\begin{array}{l}.248^{* * * \%} \\
(.010)\end{array}$ & $\begin{array}{r}-.006 \\
(.005)\end{array}$ & $\begin{array}{c}-.082 \\
(.068)\end{array}$ & $\begin{array}{l}-.060 * * * \% \\
(.004)\end{array}$ \\
\hline Control (complier) mean & .30 & .10 & & .04 & .08 & \\
\hline Very late SAT-taker, black & $\begin{array}{l}.030 * * * * \\
(.007)\end{array}$ & $\begin{array}{l}.385 \% * \% \\
(.085)\end{array}$ & $\begin{array}{l}.207 * * * * \% \\
(.009)\end{array}$ & $\begin{array}{r}-.016 * \\
(.009)\end{array}$ & $\begin{array}{r}-.206^{*} \\
(.116)\end{array}$ & $\begin{array}{l}-.061 * * * \% \\
(.004)\end{array}$ \\
\hline Control (complier) mean & .16 & .00 & & .05 & .21 & \\
\hline
\end{tabular}

NoTE.-Columns 1 and 4 present reduced form estimates of the impact of eligibility on BA and AA completion within 6 years of high school graduation. Columns 2 and 5 present instrumental variables estimates of the impact of GSUS enrollment on degree completion, with GSUS enrollment instrumented by eligibility. Columns 3 and 6 present OLS estimates of the impact of GSUS enrollment on degree completion. Columns 1 and 4 list the mean completion rates for those 10 SAT points below the threshold, while cols. 2 and 5 list the predicted completion rates for untreated compliers. All regressions use a bandwidth of 60 and include high school class fixed effects. Heteroskedasticity robust standard errors clustered by distance to the admissions threshold are in parentheses.

$* p<.10$.

$\because \% p<.05$.

$* * * 0.01$.

at least marginally statistically significant. Discontinuities in degree completion are also visually apparent in most of the panels of figure 4. For the sample as a whole, GSUS eligibility raises bachelor's degree completions rates by 0.9 percentage points. Scaled by the first stage, this implies that eligibilityinduced enrollment into 4-year public colleges raises the probability of completing a bachelor's degree by 41 percentage points. Estimated impacts on compliers in the disadvantaged subsamples are quite similar, ranging in magnitude from 29-43 percentage points. Low control complier means imply that, for the entire sample and all disadvantaged subsamples, enrollment in the 4-year public sector at least triples bachelor's degree completion rates.

Three other facts are worth noting. First, the increase in bachelor's degree completion driven in part by a shift away from 2-year colleges does not decrease associate's degree completion rates in any statistically significant way. This implies that few of the marginal students would have instead 

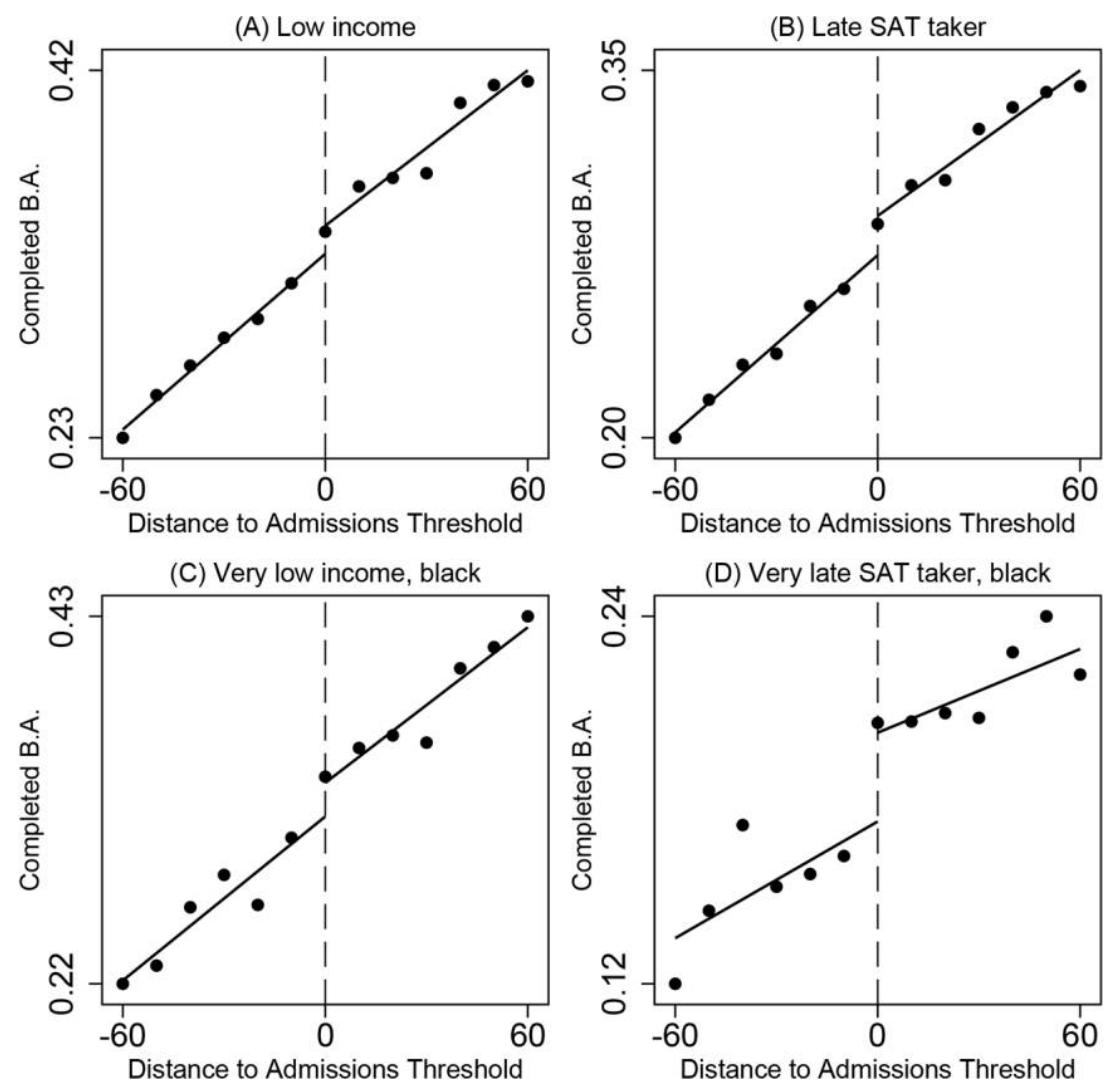

FIG. 4.-Bachelor's degree completion. Each panel shows the fraction of students completing a bachelor's degree within 6 years of high school graduation, as a function of the distance of students' first SAT scores from the GSUS eligibility threshold. Panel $A$ includes students who reported family incomes below $\$ 60,000$. Panel $B$ includes students who took their first SAT no more than 12 months prior to June of their high school graduation year. Panels $C$ and $D$ include black students who, respectively, reported family income of less than $\$ 30,000$ and took their first SAT no more than 6 months prior to June of their high school graduation year. Also shown are fitted regression lines from the baseline specification using a bandwidth of 60 points.

completed their associate's degrees if denied access to the 4-year sector. Second, across most of the coefficients shown here, IV and OLS analyses yield estimates that are fairly close in magnitude and statistically indistinguishable. This suggests that our controls for academic skill, namely SAT scores, are rich enough to soak up much of the omitted variable bias one might otherwise worry about in non-quasi-experimental estimates. Third, comparing the estimates in column 2 to those in column 6 of the previous table suggests 
that differences in the institutional bachelor's degree completion rates of students' initial colleges explain quite well their own probabilities of bachelor's degree completion. In other words, institution-level completion rates predict individual completion rates of compliers fairly accurately, at least conditional on students' own academic skills.

All of the 4-year college enrollment and bachelor's degree completion rate estimates are qualitatively robust to using alternative bandwidths and to the inclusion of demographic controls (see table A3). A number of placebo tests confirm that these results are not driven by spurious characteristics of the data or functional form assumptions of our specifications (see appendix table A4). Shifting the thresholds in either direction diminishes the magnitude and statistical significance of the GSUS enrollment and bachelor's degree completion estimates, implying that the clearest discontinuities are at the correct thresholds themselves. The advantaged subsamples of students whose GSUS enrollment is unaffected by the thresholds also show no discontinuity in degree completion rates. ${ }^{9}$ GSUS thresholds have no impact on the degree completion rates of low-income students outside of Georgia for whom the GSUS admissions process is largely irrelevant. In summary, our observed effects appear only for disadvantaged students in Georgia and only at the precise values of the GSUS thresholds.

Our results also do not depend on our choice to use the minimum distance to the two thresholds as the running variable. We can replace that collapsed two-dimensional measure with alternative one-dimensional measures of distance to either the math or the verbal threshold, eliminating the second dimension by conditioning the sample on satisfying the other subject's threshold. These alternatives lead to point estimates that are generally at least as large as those from the minimum distance measure and statistically significant for all disadvantaged subsamples. ${ }^{10}$ Our estimates are thus robust to alternate definitions of the running variable.

\section{SAT-Retaking Behavior}

Access to the in-state 4-year public sector has large benefits to the marginal student studied here. We now provide evidence that the marginal student perceives at least some of the value of this option. Because the Georgia thresholds are publicly known, students who fail to meet those thresholds on their first attempt may retake the SAT in order to gain access to the instate 4-year public sector. Figure 5 shows the graphical version of this relationship between retake probability and distance from the GSUS threshold.

${ }^{9}$ Appendix figure A3 confirms this visually.

${ }^{10}$ See appendix table A5. Appendix figure A4 shows the reduced form versions of these alternate measures for the subsample of late SAT-takers, with clearly visible discontinuities in GSUS enrollment and bachelor's degree completion at both the math and verbal thresholds. 


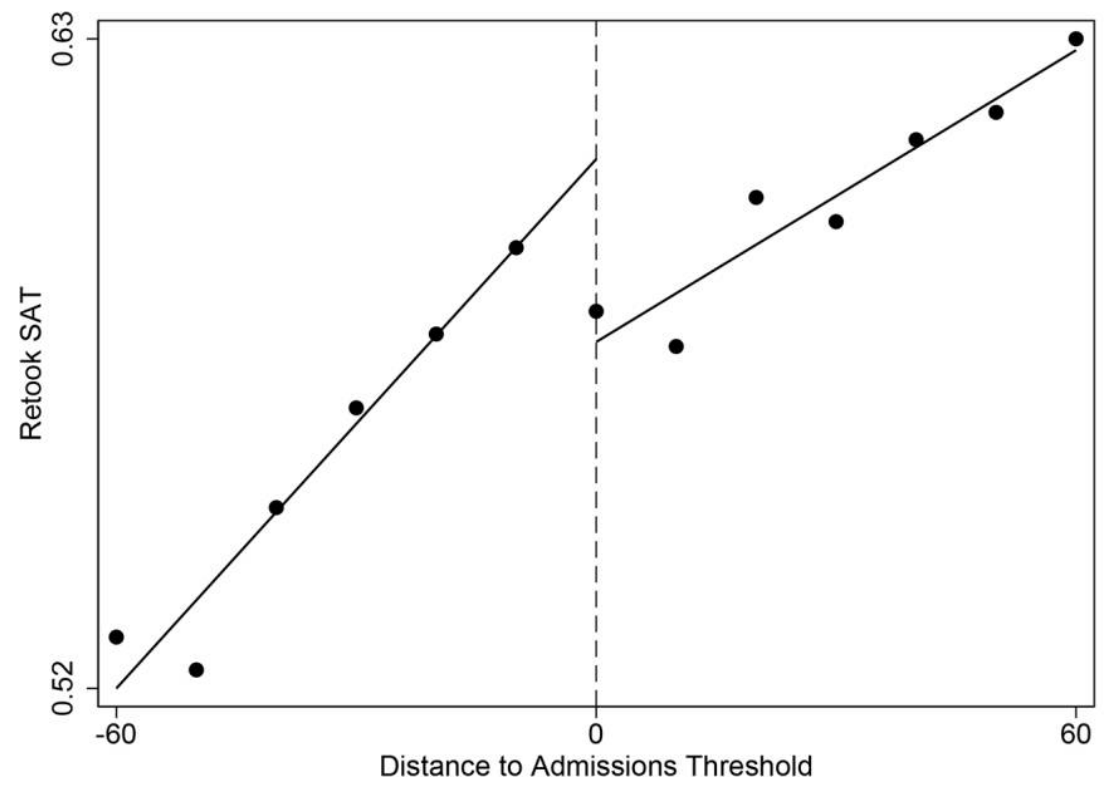

FIG. 5.-SAT-retaking. Shown above is the fraction of students retaking the SAT at least once, as a function of the distance of students' first SAT scores from the GSUS eligibility threshold. Also shown are fitted regression lines from the baseline specification using a bandwidth of 60 points.

Retaking rates rise with SAT score in this part of the score distribution, and near the threshold roughly $60 \%$ of students retake the exam. The figure shows a small but clear discontinuity, with those just below the threshold more likely to retake than those just above.

Table 5 presents formal estimates of this discontinuity, running reduced form equation with SAT-retaking measures as outcomes. We also replace the Access variable with 1 - Access, so that the coefficients can be interpreted as the impact of missing the thresholds, rather than achieving them, on one's first take. Panel A shows that, for the full sample, just missing the threshold increases the probability of retaking by 3 percentage points. This is clear evidence of demand for access to the 4-year public sector, given that there is no other reason why this threshold should trigger differential retake rates. Given the degree completion benefits of access to this sector, however, this documented demand is arguably lower than it should be. Retaking the SAT is relatively inexpensive but would yield substantial gains in college access and completion for students near these thresholds.

We also document in panel B that, though retaking in reaction to the threshold does not vary much by income, overall levels of retaking do. At the threshold, $51 \%$ of low-income students retake the SAT, with the mean student taking the exam 1.7 times. For non-low-income students near 
Table 5

SAT-Retaking Behavior

\begin{tabular}{|c|c|c|c|c|}
\hline & $\begin{array}{l}\text { Retook } \\
\text { SAT } \\
(1) \\
\end{array}$ & $\begin{array}{l}\text { Number of } \\
\text { Takes } \\
(2)\end{array}$ & $\begin{array}{l}\text { Ever GSUS } \\
\text { Eligible } \\
(3)\end{array}$ & $\begin{array}{c}\text { Maximum } \\
\text { SAT } \\
(4) \\
\end{array}$ \\
\hline \multicolumn{5}{|l|}{ A. All students: } \\
\hline All & $\begin{array}{l}.031 \% * \% \\
(.005)\end{array}$ & $\begin{array}{l}.047 \% * * \% \\
(.012)\end{array}$ & $\begin{array}{l}-.509 * * \% \\
(.004)\end{array}$ & $\begin{array}{l}2.691^{* * *} \\
(1.029)\end{array}$ \\
\hline Control mean & .58 & 1.87 & 1.00 & 936.15 \\
\hline \multicolumn{5}{|l|}{ B. By income: } \\
\hline Non-low income & $\begin{array}{l}.032^{* *} \\
(.011)\end{array}$ & $\begin{array}{l}.071 * * \% \\
(.021)\end{array}$ & $\begin{array}{c}-.412^{* * * *} \\
(.009)\end{array}$ & $\begin{array}{l}4.273 * * \\
(1.679)\end{array}$ \\
\hline Control mean & .66 & 2.02 & 1.00 & 947.52 \\
\hline Low income & $\begin{array}{l}.037 * * * * \\
(.007)\end{array}$ & $\begin{array}{l}.049 * \% * \\
(.010)\end{array}$ & $\begin{array}{l}-.596 \% * \% \\
(.007)\end{array}$ & $\begin{array}{c}2.338 \\
(1.839)\end{array}$ \\
\hline Control mean & .51 & 1.71 & 1.00 & 922.50 \\
\hline \multicolumn{5}{|l|}{ C. By SAT-taking date: } \\
\hline Early SAT-taker & $\begin{array}{l}.011^{\cdots * * *} \\
(.003)\end{array}$ & $\begin{array}{l}.007 \\
(.020)\end{array}$ & $\begin{array}{c}-.300 * * * \% \\
(.003)\end{array}$ & $\begin{array}{c}1.942 \\
(1.270)\end{array}$ \\
\hline Control mean & .80 & 2.34 & 1.00 & 964.90 \\
\hline Late SAT-taker & $\begin{array}{l}.030 \% * \% \\
(.007)\end{array}$ & $\begin{array}{l}.041 \% * * \\
(.008)\end{array}$ & $\begin{array}{l}-.700 * * * \% \\
(.005)\end{array}$ & $\begin{array}{c}.814 \\
(1.323)\end{array}$ \\
\hline Control mean & .40 & 1.47 & 1.00 & 911.40 \\
\hline
\end{tabular}

NOTE.-Each coefficient is a reduced form estimate of the impact of initially scoring below the GSUS threshold on the listed outcome. Low-income students are those reporting family income less than $\$ 60,000$. Late SAT-takers are those who took their first SAT no more than 12 months prior to June of their high school graduation year. Listed below each estimate is the mean outcome for students at the threshold. All regressions use a bandwidth of 60 and include high school class fixed effects. Heteroskedasticity robust standard errors clustered by distance to the admissions threshold are in parentheses.

$* * p<.05$.

$\because * \% p<.01$.

the threshold, $66 \%$ retake for a mean number of takes of 2.0. Retaking rates are thus substantially higher for higher-income students, even conditional on first SAT score. The result is that first SAT scores are a much stronger determinant of eventual access to GSUS for low-income students than for higher-income students. As shown in column 3, retaking more frequently means that only $41 \%$ of non-low-income students whose first SAT is just below the threshold ultimately fail to score high enough to qualify for access, compared to $60 \%$ of low-income students. This at least partly explains why our first SAT-score-based instrument is much stronger for low-income students than their higher-income counterparts.

These disparities are even more striking when comparing early to late SATtakers, as panel C does. Only 30\% of early SAT-takers who miss the threshold on their first take do not eventually score high enough to access the 4-year public sector. Early SAT-takers take the test an average of 2.3 times, with $80 \%$ retaking it at least once. Late SAT-takers, who have less time to schedule retakes and may be less aware of the potential benefits of retaking, take the 
test an average of 1.47 times, with only $40 \%$ retaking it at least once. As a result, $70 \%$ of late SAT-takers who fail to meet the thresholds on the first take ultimately fail to gain access to the 4-year public sector.

Finally, though we provide clear evidence of endogenous retaking due to demand for access to the 4-year public sector, the amount of such retaking is particularly small relative to overall retaking rates. Of the $60 \%$ of students just below the threshold who retake the SAT, roughly $3 \%$, or 1 in 20 , are retaking specifically to gain access to GSUS. The remaining $57 \%$ are likely retaking to improve their college options generally and would have retaken in the absence of the minimum GSUS thresholds. Because overall retake rates are so high near the threshold, maximum SAT scores show small and often statistically insignificant discontinuities there, as seen in column 4.

The result is that, though we use first SAT scores throughout this paper, using maximum SAT scores to generate variation in college access is unlikely to introduce much endogeneity. Indeed, when we rerun our analyses using maximum SAT scores to generate the running variable, the magnitudes of our central estimates are still extremely large, statistically significant, and more precisely estimated due to a much larger first stage. ${ }^{11}$ These results also imply that access to the 4-year public sector greatly increases bachelor's degree completion rates, with estimated impacts from instrumental variables models of similar magnitude to corresponding OLS estimates.

\section{Discussion and Conclusion}

For relatively low-skilled students in Georgia, access to the 4-year public sector substantially increases bachelor's degree completion rates. It does so by increasing both the probability of enrollment in any 4-year college and the quality of college chosen, largely by diverting students from 2-year colleges. That students retake the SAT in order to gain access to the 4-year public sector suggests that they perceive at least some, though perhaps not all, of this benefit. We draw three broad lessons from these findings.

First, that small differences in test scores generate large differences in college choice suggests that students are not applying to a continuum of college options, perhaps because such a continuum does not exist in the postsecondary market. In Georgia and other states, a student denied access to the 4-year public sector does not have other options similar in both price and quality. Community colleges are less expensive but have less money to spend on faculty and other resources to support students' progress toward degree completion. Private 4-year colleges potentially of interest to the marginal student here cannot match the public sector's tuition while maintaining comparable quality, given the in-kind nature of state subsidies for higher education. Regardless of the lack of such a continuum of college

${ }^{11}$ See appendix table A6, which replicates table 4 using maximum SAT scores instead of first SAT scores. 
options, our results reinforce the benefits of encouraging students to make test-taking and application choices that maximize their available postsecondary options. The thresholds used by Georgia heighten the importance of such choices, with unclear benefits to the state more broadly.

Second, that college sector and quality affect degree completion for relatively low-skilled students is inconsistent with claims that disadvantaged students benefit from choosing colleges that enroll higher proportions of similar peers. By the nature of these minimum thresholds, the marginal student in this study benefits, in terms of degree completion, from enrolling in a college where he/she is substantially less academically skilled than his/her peers. This implies that measures of absolute quality matter more than "match" quality. Our estimates reject the hypothesis that low-skilled students should be discouraged from choosing 4-year colleges because they are incapable of completing degrees at such institutions. A substantial fraction of the marginal students we study do succeed in completing their bachelor's degrees, a result consistent with naive OLS estimates. This finding also bears directly on the debate over affirmative action, as it contradicts the view that students benefit from attending colleges with less academically skilled peers. ${ }^{12}$

Third, our estimates suggest one potential concern about policies to reduce the cost of community college, such as the Tennessee Promise scholarship or the Obama administration's free community college proposal. Lowering such costs may improve college enrollment and degree completion for students who would not otherwise have attended college. By changing the relative price of the 2- and 4-year sectors, such programs may, however, lower degree completion rates for students drawn out of the 4-year sector and into the 2-year sector. This is particularly true given the large existing disparities in degree completion rates between these two sectors and our finding that institutional completion rates are strong predictors of degree completion, particularly for disadvantaged students who are likely most price sensitive. The net completion effect of such proposals thus depends, in part, on the number of students on the margin between no college and a 2-year college and the number on the margin between a 2-year college and a 4-year college. Early evidence from Tennessee suggests that the latter number is nontrivial (Carruthers and Fox 2016). ${ }^{13}$ Our results sug-

${ }^{12}$ A prominent example of this view arose during oral arguments for the Fisher $v$. University of Texas at Austin affirmative action case, when Supreme Court Justice Antonin Scalia noted that, "There are those who contend that it does not benefit African-Americans to get them into the University of Texas where they do not do well, as opposed to having them go to a less-advanced school, a slower-track school where they do well."

${ }^{13}$ In the first year of the Tennessee Promise scholarship, the state saw a $25 \%$ increase in community college enrollment but a $5 \%-8 \%$ decrease in enrollment at 4-year public institutions (Ashley A. Smith, "Promise Provides Enrollment Boost," Inside Higher Ed, November 24, 2015). 
gest that policy makers should account for such students when designing proposals to change the price, and potentially quality, of the community college sector.

Our work provides some of the clearest evidence to date on the importance of initial college choice for students with relatively low academic skills. Further research is needed to determine why college choice matters and which aspects of the college experience are responsible for the degree completion effects we document. We also hope in future work to determine how these degree completion effects translate into labor market outcomes.

\section{Appendix}

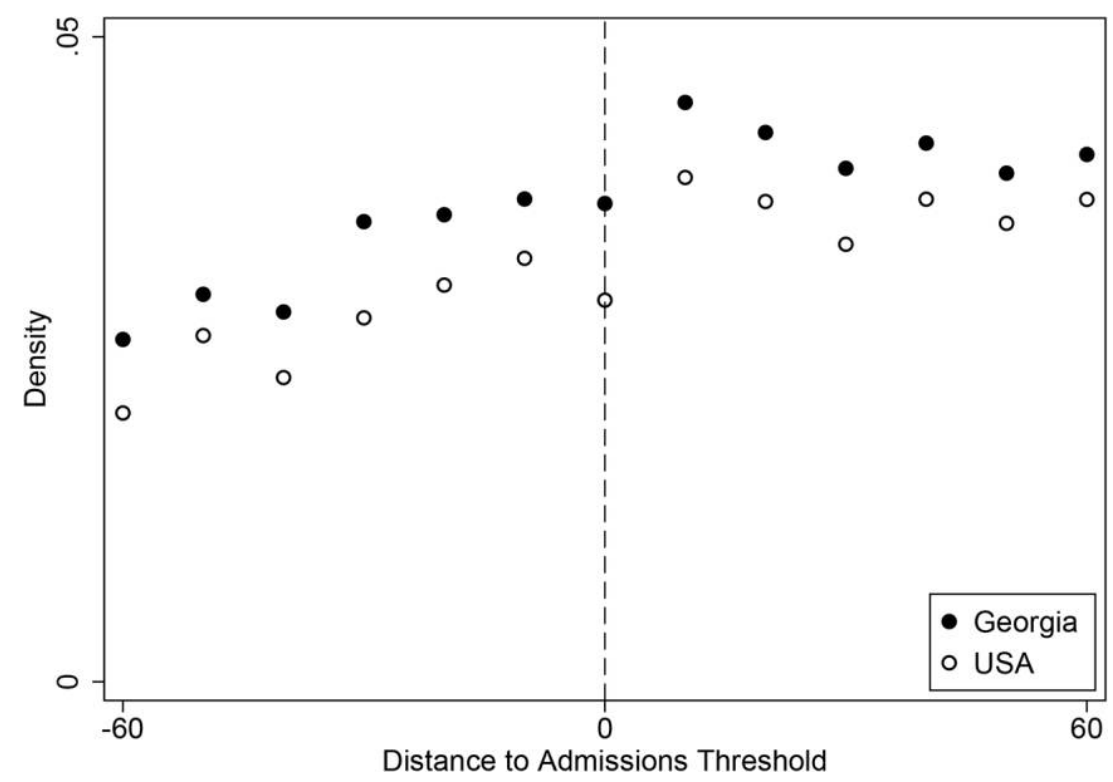

FIG. A1.-Density of distances to the threshold. The closed circles show the fraction of Georgia students whose first SAT scores place them at a given distance from the GSUS eligibility threshold. The open circles show the fraction of nonGeorgia students whose first SAT scores place them at that distance. Both samples consist of the 2004-8 graduating high school classes. 

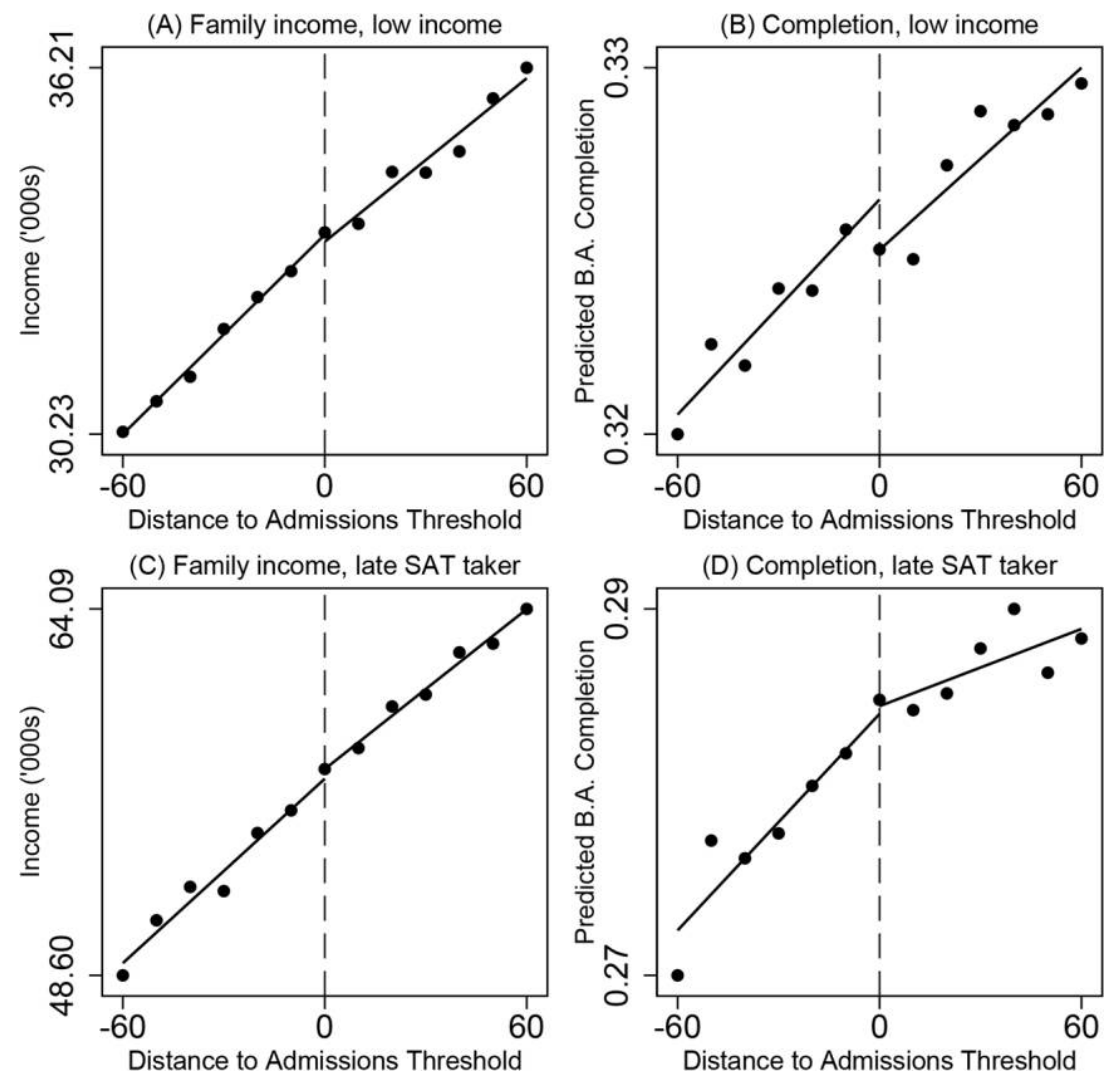

FIG. A2.-Covariate balance. Panels $A$ and $C$ show mean reported income for low-income and late-SAT-taking students, respectively, as a function of the distance of students' first SAT scores from the GSUS eligibility threshold. Panels $B$ and $D$ show the mean predicted BA completion rates for low-income and late-SATtaking students, respectively, with predictions based on gender, race, family income, and parental education. Also shown are fitted regression lines from the baseline specification using a bandwidth of 60 points. 

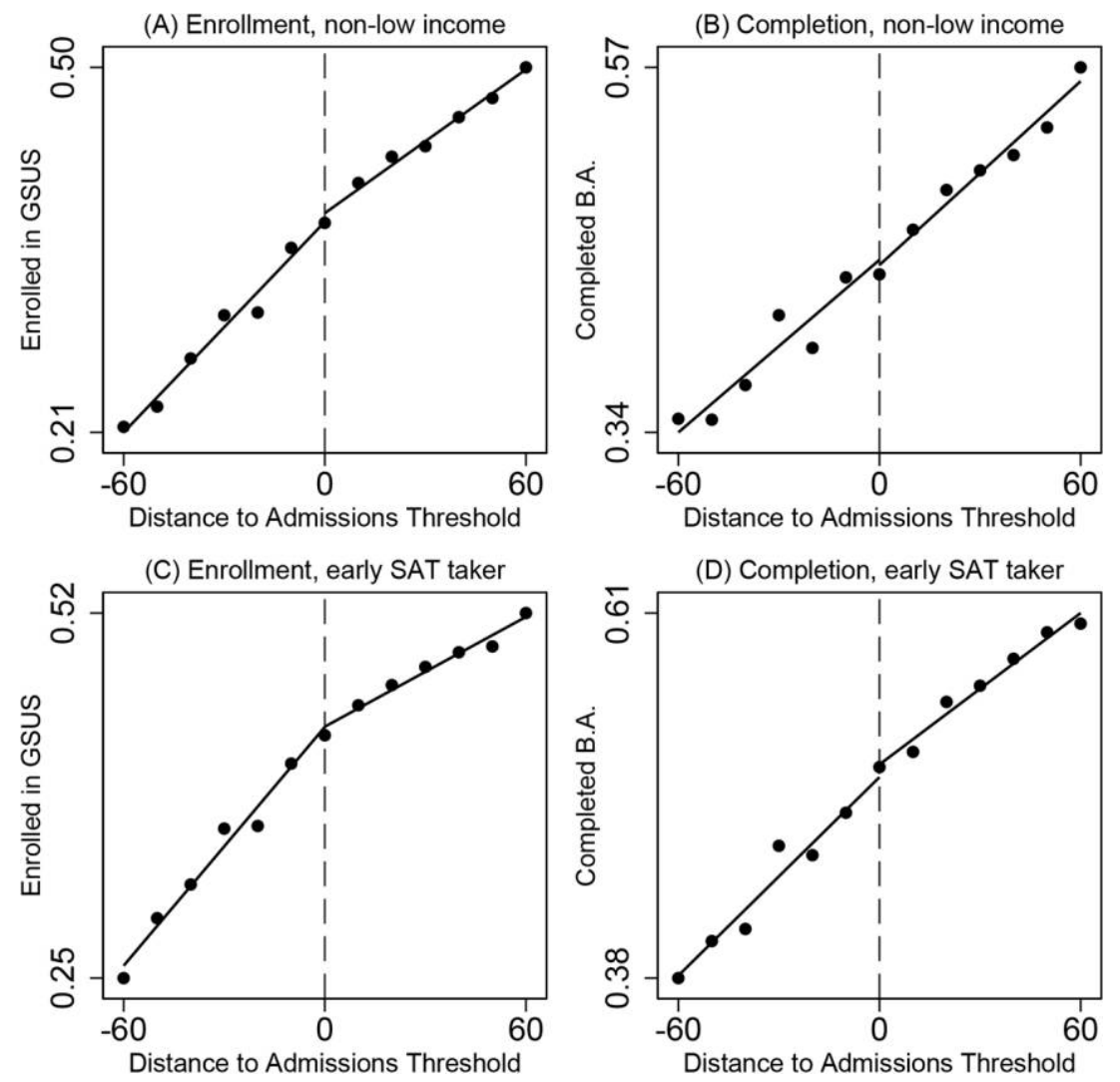

FIG. A3.-Placebo tests. Panels $A$ and $C$ show mean GSUS enrollment rates for non-low-income and early-SAT-taking students, respectively, as a function of the distance of students' first SAT scores from the GSUS eligibility threshold. Panels $B$ and $D$ show the mean BA completion rates for non-low-income and early-SAT-taking students, respectively. Also shown are fitted regression lines from the baseline specification using a bandwidth of 60 points. 

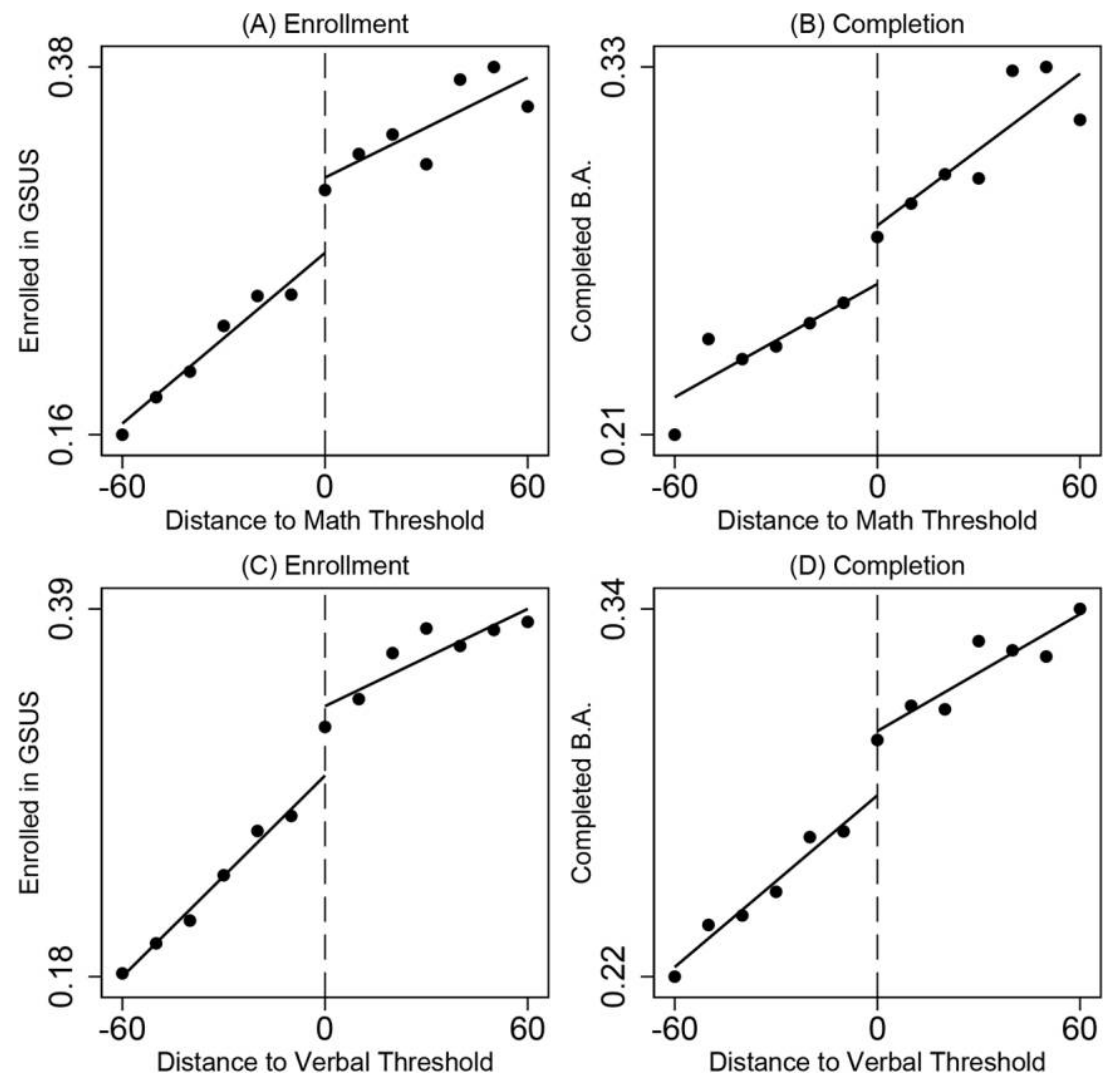

FIG. A4.- Alternative distance measures. Panels $A$ and $B$ show mean GSUS enrollment rates and BA completion rates as a function of the distance of students' first SAT scores from the math threshold. Panels $C$ and $D$ show such outcomes as a function of the distance of students' first SAT scores from the verbal threshold. The sample in each panel consists of late SAT-takers whose other SAT subject score satisfies the GSUS eligibility requirements. Also shown are fitted regression lines from the baseline specification using a bandwidth of 60 points. 


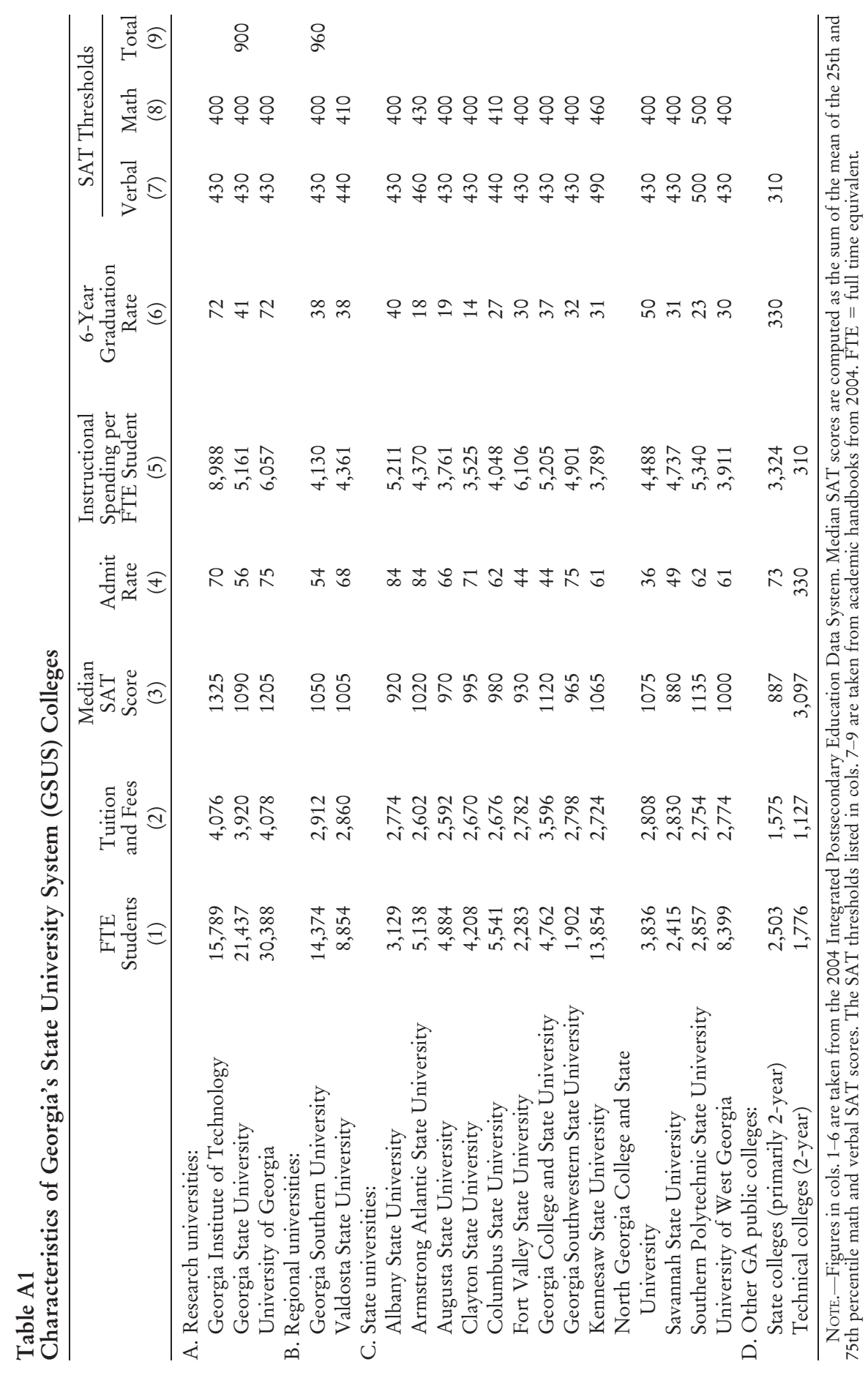




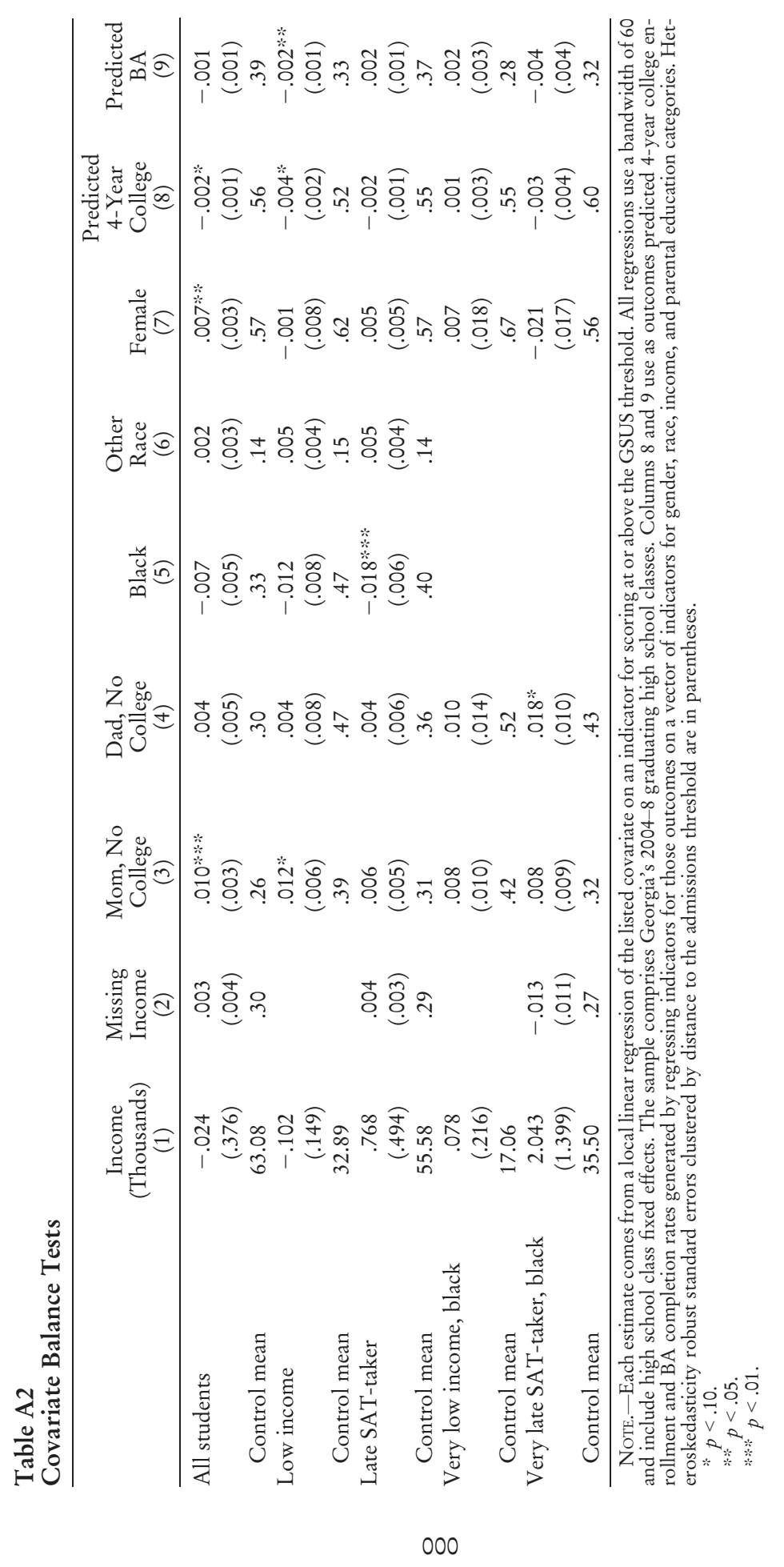

This content downloaded from 128.103.193.204 on April 03, 2017 14:20:35 PM All use subject to University of Chicago Press Terms and Conditions (http://www.journals.uchicago.edu/t-and-c). 
Table A3

Robustness Checks

$\begin{array}{llllll}(1) & (2) & (3) & (4) & (5) & (6)\end{array}$

\begin{tabular}{|c|c|c|c|c|c|c|}
\hline $\begin{array}{l}\text { Enrolled in } \\
\text { 4-year college: }\end{array}$ & & & & & & \\
\hline All students & $\begin{array}{l}.739 \% * * \\
(.231)\end{array}$ & $\begin{array}{l}.813 * * * \\
(.180)\end{array}$ & $\begin{array}{l}.813 * * * \\
(.143)\end{array}$ & $\begin{array}{l}.776 * * * \\
(.116)\end{array}$ & $\begin{array}{l}.748^{* * * *} \\
(.083)\end{array}$ & $\begin{array}{l}.794 * \cdots * \% \\
(.086)\end{array}$ \\
\hline Low income & $\begin{array}{l}.573 \% * \% \\
(.093)\end{array}$ & $\begin{array}{l}.695 * * * \% \\
(.085)\end{array}$ & $\begin{array}{l}.648 \% * * \\
(.082)\end{array}$ & $\begin{array}{l}.624 * * * \% \\
(.077)\end{array}$ & $\begin{array}{l}.687 * * * * \\
(.074)\end{array}$ & $\begin{array}{l}.747 * \cdots * \% \\
(.080)\end{array}$ \\
\hline Late SAT-taker & $\begin{array}{l}.614 * * * * \\
(.103)\end{array}$ & $\begin{array}{l}.648^{* * * *} \\
(.088)\end{array}$ & $\begin{array}{l}.666^{* \cdots * *} \\
(.075)\end{array}$ & $\begin{array}{l}.636^{* * * *} \\
(.076)\end{array}$ & $\begin{array}{l}.697 * * * * \\
(.061)\end{array}$ & $\begin{array}{l}.738^{* * * *} \\
(.059)\end{array}$ \\
\hline $\begin{array}{l}\text { Very low } \\
\text { income, black }\end{array}$ & $\begin{array}{l}.744 \% * \% \\
(.125)\end{array}$ & $\begin{array}{l}.603^{* * * *} \\
(.175)\end{array}$ & $\begin{array}{l}.663^{* * * \%} \\
(.136)\end{array}$ & $\begin{array}{l}.682 * * * * \\
(.132)\end{array}$ & $\begin{array}{l}.657^{* * * *} \\
(.134)\end{array}$ & $\begin{array}{l}.662 * * \% * \\
(.138)\end{array}$ \\
\hline $\begin{array}{l}\text { Very late SAT- } \\
\text { taker, black }\end{array}$ & $\begin{array}{l}.784 \% * \% \\
(.198)\end{array}$ & $\begin{array}{l}.833 \cdots * * \% \\
(.132)\end{array}$ & $\begin{array}{l}.753 \% * \% \\
(.124)\end{array}$ & $\begin{array}{l}.702 * \% * \\
(.127)\end{array}$ & $\begin{array}{l}.765^{* * * *} \\
(.109)\end{array}$ & $\begin{array}{l}.758^{* * * *} \\
(.109)\end{array}$ \\
\hline Completed BA: & & & & & & \\
\hline All students & $\begin{array}{l}.432 \% * \\
(.170)\end{array}$ & $\begin{array}{l}.285^{*} \\
(.158)\end{array}$ & $\begin{array}{l}.410 * \cdots * \% \\
(.131)\end{array}$ & $\begin{array}{l}.454 * * * \% \\
(.102)\end{array}$ & $\begin{array}{l}.394 \% * \% \\
(.077)\end{array}$ & $\begin{array}{l}.388^{* * * \%} \\
(.060)\end{array}$ \\
\hline Low income & $\begin{array}{l}.555^{* * *} \\
(.172)\end{array}$ & $\begin{array}{l}.436 \% * \% \\
(.141)\end{array}$ & $\begin{array}{l}.425^{* \cdots *} \\
(.128)\end{array}$ & $\begin{array}{l}.411 \% * \% \\
(.125)\end{array}$ & $\begin{array}{l}.484 \% * * \\
(.118)\end{array}$ & $\begin{array}{l}.503 * * * \% \\
(.121)\end{array}$ \\
\hline Late SAT-taker & $\begin{array}{l}.517 \% * * \\
(.078)\end{array}$ & $\begin{array}{l}.457^{* * * *} \\
(.068)\end{array}$ & $\begin{array}{l}.424 \% * \% \\
(.061)\end{array}$ & $\begin{array}{l}.415^{* * * \%} \\
(.060)\end{array}$ & $\begin{array}{l}.435^{* * * *} \\
(.056)\end{array}$ & $\begin{array}{l}.419 * * * \% \\
(.048)\end{array}$ \\
\hline $\begin{array}{l}\text { Very low } \\
\text { income, black }\end{array}$ & $\begin{array}{l}.481 * * \\
(.209)\end{array}$ & $\begin{array}{l}.340 * \\
(.176)\end{array}$ & $\begin{array}{l}.289 * \\
(.154)\end{array}$ & $\begin{array}{l}.350 * * \\
(.155)\end{array}$ & $\begin{array}{l}.354 * * * * \\
(.124)\end{array}$ & $\begin{array}{l}.353^{* * * *} \\
(.113)\end{array}$ \\
\hline $\begin{array}{c}\text { Very late SAT- } \\
\text { taker, black }\end{array}$ & $\begin{array}{l}.806^{* \% * \%} \\
(.217)\end{array}$ & $\begin{array}{l}.449 \% * \% \\
(.104)\end{array}$ & $\begin{array}{l}.385^{* * * \%} \\
(.085)\end{array}$ & $\begin{array}{l}.446^{* * * *} \\
(.106)\end{array}$ & $\begin{array}{l}.393 * * * \% \\
(.088)\end{array}$ & $\begin{array}{l}.418^{* * * * * 6} \\
(.091)\end{array}$ \\
\hline Bandwidth & 40 & 50 & 60 & 70 & 80 & 80 \\
\hline Demographic controls & No & No & No & No & No & Yes \\
\hline
\end{tabular}

NoTE.-All coefficients are instrumental variables estimates of the impact of GSUS enrollment on the panel's listed outcome, with GSUS enrollment instrumented by eligibility. All regressions use a bandwidth of 60 and include high school class fixed effects. Column 6 also includes controls for gender, race, family income, and parental education. Heteroskedasticity robust standard errors clustered by distance to the admissions threshold are in parentheses.

$* p<.10$.

$* \%<<.05$.

$* * * 01$.

This content downloaded from 128.103.193.204 on April 03, 2017 14:20:35 PM

All use subject to University of Chicago Press Terms and Conditions (http://www.journals.uchicago.edu/t-and-c). 
Table A4

Placebo Tests

\begin{tabular}{|c|c|c|c|c|c|}
\hline & \multicolumn{5}{|c|}{ Eligibility Threshold Shifted by: } \\
\hline & $\begin{array}{l}-20 \\
(1)\end{array}$ & $\begin{array}{l}-10 \\
(2)\end{array}$ & $\begin{array}{c}0 \\
(3)\end{array}$ & $\begin{array}{l}10 \\
(4)\end{array}$ & $\begin{array}{l}20 \\
(5)\end{array}$ \\
\hline \multicolumn{6}{|l|}{ A. Enrolled, GSUS college: } \\
\hline All students & $\begin{array}{r}-.006 \\
(.005)\end{array}$ & $\begin{array}{c}.005 \\
(.006)\end{array}$ & $\begin{array}{l}.021 * * * \\
(.005)\end{array}$ & $\begin{array}{l}.021 * * \\
(.009)\end{array}$ & $\begin{array}{c}.014 \\
(.010)\end{array}$ \\
\hline Low income & $\begin{array}{r}-.010 \\
(.008)\end{array}$ & $\begin{array}{c}.008 \\
(.014)\end{array}$ & $\begin{array}{l}.036^{* * * *} \\
(.007)\end{array}$ & $\begin{array}{c}.020 \\
(.016)\end{array}$ & $\begin{array}{l}.019 \% \\
(.010)\end{array}$ \\
\hline Late SAT-taker & $\begin{array}{r}-.007 \\
(.008)\end{array}$ & $\begin{array}{c}.013 \\
(.014)\end{array}$ & $\begin{array}{l}.044^{* * * *} \\
(.007)\end{array}$ & $\begin{array}{l}.023 \\
(.015)\end{array}$ & $\begin{array}{l}.024 * * \\
(.011)\end{array}$ \\
\hline Very low income, black & $\begin{array}{r}-.027 \\
(.017)\end{array}$ & $\begin{array}{c}.016 \\
(.025)\end{array}$ & $\begin{array}{l}.070 * * * \\
(.014)\end{array}$ & $\begin{array}{l}.026 \\
(.033)\end{array}$ & $\begin{array}{c}.014 \\
(.026)\end{array}$ \\
\hline Very late SAT-taker, black & $\begin{array}{c}-.030 \\
(.022)\end{array}$ & $\begin{array}{c}.005 \\
(.033)\end{array}$ & $\begin{array}{l}.079 * * * \\
(.009)\end{array}$ & $\begin{array}{c}.041 \\
(.032)\end{array}$ & $\begin{array}{l}.045^{* *} \\
(.020)\end{array}$ \\
\hline Non-low income & $\begin{array}{c}-.001 \\
(.006)\end{array}$ & $\begin{array}{c}.002 \\
(.006)\end{array}$ & $\begin{array}{c}.007 \\
(.011)\end{array}$ & $\begin{array}{l}.024 \% * \\
(.010)\end{array}$ & $\begin{array}{c}.003 \\
(.012)\end{array}$ \\
\hline Early SAT-taker & $\begin{array}{r}-.007 \\
(.005)\end{array}$ & $\begin{array}{r}-.004 \\
(.004)\end{array}$ & $\begin{array}{c}.000 \\
(.008)\end{array}$ & $\begin{array}{c}.016 \\
(.012)\end{array}$ & $\begin{array}{c}.000 \\
(.012)\end{array}$ \\
\hline B. Completed BA: & & & & & \\
\hline All students & $\begin{array}{c}.006 * \\
(.003)\end{array}$ & $\begin{array}{c}.002 \\
(.004)\end{array}$ & $\begin{array}{l}.009 * * \\
(.003)\end{array}$ & $\begin{array}{l}.006 \\
(.005)\end{array}$ & $\begin{array}{c}.001 \\
(.006)\end{array}$ \\
\hline Low income & $\begin{array}{c}-.009 \\
(.007)\end{array}$ & $\begin{array}{c}.006 \\
(.008)\end{array}$ & $\begin{array}{l}.015^{* * * *} \\
(.004)\end{array}$ & $\begin{array}{c}.008 \\
(.006)\end{array}$ & $\begin{array}{l}.005 \\
(.006)\end{array}$ \\
\hline Late SAT-taker & $\begin{array}{c}-.003 \\
(.006)\end{array}$ & $\begin{array}{c}.006 \\
(.008)\end{array}$ & $\begin{array}{l}.019 * * * \\
(.004)\end{array}$ & $\begin{array}{l}.006 \\
(.007)\end{array}$ & $\begin{array}{c}.010 \\
(.005)\end{array}$ \\
\hline Very low income, black & $\begin{array}{c}-.006 \\
(.011)\end{array}$ & $\begin{array}{c}.004 \\
(.013)\end{array}$ & $\begin{array}{l}.020 * \\
(.011)\end{array}$ & $\begin{array}{c}.017 \\
(.015)\end{array}$ & $\begin{array}{r}-.009 \\
(.013)\end{array}$ \\
\hline Very late SAT-taker, black & $\begin{array}{c}.002 \\
(.015)\end{array}$ & $\begin{array}{c}.015 \\
(.017)\end{array}$ & $\begin{array}{l}.030 \% * \% \\
(.007)\end{array}$ & $\begin{array}{l}.005 \\
(.014)\end{array}$ & $\begin{array}{r}-.002 \\
(.013)\end{array}$ \\
\hline Non-low income & $\begin{array}{c}.007 \\
(.006)\end{array}$ & $\begin{array}{c}.003 \\
(.008)\end{array}$ & $\begin{array}{r}-.003 \\
(.012)\end{array}$ & $\begin{array}{c}.014 \\
(.015)\end{array}$ & $\begin{array}{c}-.016 \\
(.014)\end{array}$ \\
\hline Early SAT-taker & $\begin{array}{c}.005 \\
(.006)\end{array}$ & $\begin{array}{r}-.004 \\
(.006)\end{array}$ & $\begin{array}{c}.008 \\
(.007)\end{array}$ & $\begin{array}{c}.005 \\
(.011)\end{array}$ & $\begin{array}{c}-.010 \\
(.011)\end{array}$ \\
\hline Low income, non-Georgia & $\begin{array}{c}.003 \\
(.002)\end{array}$ & $\begin{array}{c}.001 \\
(.003)\end{array}$ & $\begin{array}{r}-.002 \\
(.003)\end{array}$ & $\begin{array}{l}.006 \\
(.004)\end{array}$ & $\begin{array}{l}.010 * * * \\
(.002)\end{array}$ \\
\hline
\end{tabular}

NOTE.-All coefficients are reduced form estimates of the impact of GSUS eligibility on the panel's listed outcome, with the threshold shifted by the specified distance. The final row's sample comprises low-income SAT-takers outside of Georgia. All regressions use a bandwidth of 60 and include high school class fixed effects. Heteroskedasticity robust standard errors clustered by distance to the admissions threshold are in parentheses.

$$
\begin{aligned}
& * p<.10 . \\
& * * p<.05 . \\
& * * * p<.01 .
\end{aligned}
$$


Table A5

Alternative Distance Measures

\begin{tabular}{ccc}
\multicolumn{3}{c}{ Running Variable } \\
\hline Both Math and Verbal & Math & Verbal \\
(1) & (2) & (3)
\end{tabular}

A. GSUS enrollment (reduced form):

All

Low income

\begin{tabular}{|c|c|c|}
\hline $.021 * * * *$ & $.024 \% *$ & $.018^{* * * 28}$ \\
\hline .005$)$ & $(.008)$ & $(.005)$ \\
\hline $.036 * \% *$ & $.048 \% *$ & $.030 * * *$ \\
\hline$(.007)$ & $(.013)$ & $(.008)$ \\
\hline $.044 * \%$ & .046 & $.041 \%$ \\
\hline .007$)$ & $(.010)$ & $(.008)$ \\
\hline
\end{tabular}

B. BA completion (reduced form):

All

$\begin{array}{lll}.009 * * & .008 & .007 \\ (.003) & (.008) & (.006) \\ .015 * * * & .028 * * & .013 * * \\ (.004) & (.013) & (.006) \\ .019 * * * & .018 * * * & .024 * * * \\ (.004) & (.005) & (.005)\end{array}$

C. BA completion (instrumental variables):

All

\begin{tabular}{lll}
$.410 * * *$ & .343 & .419 \\
$(.131)$ & $(.321)$ & $(.287)$ \\
$.425 * * *$ & $.589 * \%$ & $.425 *$ \\
$(.128)$ & $(.277)$ & $(.218)$ \\
& & \\
$.424 * * *$ & $.404 * * *$ & $.576 * \% *$ \\
$(.061)$ & $(.103)$ & $(.118)$ \\
\hline
\end{tabular}

Late SAT-taker

$(.061)$

Note.-Panels A and B show reduced form estimates of the impact of GSUS eligibility on GSUS enrollment and BA completion. Panel C shows instrumental variables estimates of the impact of GSUS enrollment on BA completion, instrumenting GSUS enrollment with eligibility. Column 1 repeats estimates from the baseline specification, using as a running variable the minimum of a student's distances to the math and verbal thresholds. Column 2 uses distance to the math threshold as a running variable and conditions the sample on satisfying the verbal threshold. Column 3 uses distance to the verbal threshold as a running variable and conditions the sample on satisfying the math threshold. All regressions use a bandwidth of 60 in the given running variable and include high school class fixed effects. Heteroskedasticity robust standard errors clustered by distance to the admissions threshold are in parentheses.

$$
\begin{aligned}
& * p<.10 . \\
& * * p<.05 . \\
& * * * p<.01 \text {. }
\end{aligned}
$$

This content downloaded from 128.103.193.204 on April 03, 2017 14:20:35 PM

All use subject to University of Chicago Press Terms and Conditions (http://www.journals.uchicago.edu/t-and-c). 
Table A6

College Degree Completion, Using Maximum SAT Scores

\begin{tabular}{|c|c|c|c|c|c|c|}
\hline & \multicolumn{3}{|c|}{ Completed BA within 6 Years } & \multicolumn{3}{|c|}{ Completed AA within 6 Years } \\
\hline & $\begin{array}{l}(\mathrm{RF}) \\
(1)\end{array}$ & $\begin{array}{l}\text { (IV) } \\
\text { (2) }\end{array}$ & $\begin{array}{c}\text { (OLS) } \\
(3)\end{array}$ & $\begin{array}{l}(\mathrm{RF}) \\
(4)\end{array}$ & $\begin{array}{l}\text { (IV) } \\
(5)\end{array}$ & $\begin{array}{c}(\mathrm{OLS}) \\
(6)\end{array}$ \\
\hline \multicolumn{7}{|l|}{ A. All students: } \\
\hline All & $\begin{array}{l}.022^{* * * \%} \\
(.002)\end{array}$ & $\begin{array}{l}.225 * * * \\
(.023)\end{array}$ & $\begin{array}{l}.244 * * * \\
(.007)\end{array}$ & $\begin{array}{c}-.002 \\
(.002)\end{array}$ & $\begin{array}{c}-.025 \\
(.023)\end{array}$ & $\begin{array}{c}-.070 * \cdots * \\
(.002)\end{array}$ \\
\hline Control (complier) mean & .30 & .31 & & .06 & .02 & \\
\hline \multicolumn{7}{|l|}{ B. Disadvantaged: } \\
\hline Low income & $\begin{array}{l}.022 * * * \% \\
(.005)\end{array}$ & $\begin{array}{l}.229 * * * \\
(.058)\end{array}$ & $\begin{array}{l}.258 * * * \\
(.005)\end{array}$ & $\begin{array}{c}-.001 \\
(.006)\end{array}$ & $\begin{array}{c}-.012 \\
(.057)\end{array}$ & $\begin{array}{c}-.077 \\
(.002)\end{array}$ \\
\hline Control (complier) mean & .27 & .29 & & .06 & .01 & \\
\hline Late SAT-taker & $\begin{array}{l}.022^{* * * *} \\
(.003)\end{array}$ & $\begin{array}{l}.251 \% * \% \\
(.040)\end{array}$ & $\begin{array}{l}.242 \% * \% \\
(.004)\end{array}$ & $\begin{array}{c}-.004 \\
(.003)\end{array}$ & $\begin{array}{c}-.044 \\
(.036)\end{array}$ & $\begin{array}{l}-.072^{* * * \%} \\
(.001)\end{array}$ \\
\hline Control (complier) mean & .24 & .23 & & .06 & .04 & \\
\hline \multicolumn{7}{|l|}{ C. Very disadvantaged: } \\
\hline Very low income, black & $\begin{array}{l}.015 \\
(.010)\end{array}$ & $\begin{array}{l}.121 \% \\
(.068)\end{array}$ & $\begin{array}{l}.235^{* * * \%} \\
(.007)\end{array}$ & $\begin{array}{c}-.009 * * \% \\
(.004)\end{array}$ & $\begin{array}{l}-.075^{* * *} \\
(.037)\end{array}$ & $\begin{array}{l}-.059 \% * * \\
(.003)\end{array}$ \\
\hline Control (complier) mean & .29 & .29 & & .05 & .08 & \\
\hline Very late SAT-taker, black & $\begin{array}{l}.039 * * * * \\
(.012)\end{array}$ & $\begin{array}{l}.383 * * * \\
(.088)\end{array}$ & $\begin{array}{l}.206 * \% * \\
(.012)\end{array}$ & $\begin{array}{c}-.012 \\
(.008)\end{array}$ & $\begin{array}{c}-.120 * \\
(.068)\end{array}$ & $\begin{array}{l}-.059 \% * \% \\
(.003)\end{array}$ \\
\hline Control (complier) mean & .18 & .00 & & .04 & .12 & \\
\hline
\end{tabular}

Note.-Distance to the threshold is defined by maximum SAT scores. Columns 1 and 4 present reduced form estimates of the impact of eligibility on BA and AA completion within 6 years of high school graduation. Columns 2 and 5 present instrumental variables estimates of the impact of GSUS enrollment on degree completion, with GSUS enrollment instrumented by eligibility. Columns 3 and 6 present OLS estimates of the impact of GSUS enrollment on degree completion. Columns 1 and 4 list the mean completion rates for those 10 SAT points below the threshold, while cols. 2 and 5 list the predicted completion rates for untreated compliers. All regressions use a bandwidth of 60 and include high school class fixed effects. Heteroskedasticity robust standard errors clustered by distance to the admissions threshold are in parentheses.

$* p<.10$.

$\because p<<.05$.

$* * * p<.01$.

\section{References}

Abadie, Alberto. 2003. Semiparametric instrumental variable estimation of treatment response models. Iournal of Econometrics 113, no. 2:231-63.

Abadie, Alberto, Joshua Angrist, and Guido Imbens. 2002. Instrumental variables estimates of the effect of subsidized training on the quantiles of trainee earnings. Econometrica 70, no. 1:91-117.

Arcidiacono, Peter, and Michael Lovenheim. 2016. Affirmative action and the quality-fit trade-off. Lournal of Economic Literature 54, no. 1:3-51. http://www.aeaweb.org/articles/?doi=10.1257/jel.54.1.3.

Bailey, Martha, and Susan Dynarski. 2011. Inequality in postsecondary education. In Whither opportunity? Rising inequality, schools, and children's life chances, ed. Greg J. Duncan and Richard J. Murnane. New York: Russell Sage Foundation. 
Belley, Philippe, and Lance Lochner. 2007. The changing role of family income and ability in determining educational achievement. Lournal of Human Capital 1, no. 1:37-89.

Bettinger, Eric P., Bridget Terry Long, Philip Oreopoulos, and Lisa Sanbonmatsu. 2012. The role of application assistance and information in college decisions: Results from the H\&R Block FAFSA experiment. Ouarterly Iournal of Economics 127, no. 3:1205-42.

Black, Dan A., and Jeffrey A. Smith. 2004. How robust is the evidence on the effects of college quality? Evidence from matching. Iournal of Econometrics 121, no. 1:99-124.

. 2006. Estimating the returns to college quality with multiple proxies for quality. Lournal of Labor Economics 24, no. 3:701-28.

Black, Dan A., Jeffrey A. Smith, and Kermit Daniel. 2005. College quality and wages in the United States. German Economic Review 6, no. 3:415-43.

Bound, John, Brad Hershbein, and Bridget Terry Long. 2009. Playing the admissions game: Student reactions to increasing college competition. Iournal of Economic Perspectives 23, no. 4:119-46.

Bound, John, Michael F. Lovenheim, and Sarah Turner. 2010. Why have college completion rates declined? An analysis of changing student preparation and collegiate resources. American Economic Iournal: Applied Economics 2, no. 3:129-57.

Bowen, William G., Matthew M. Chingos, and Michael S. McPherson. 2009. Crossing the finish line: Completing college at America's public universities. Princeton, NJ: Princeton University Press.

Briggs, Derek C. 2009. Preparation for college admission exams. Discussion paper, National Association for College Admission Counseling.

Canaan, Serena, and Pierre Mouganie. Forthcoming. Returns to education quality for low-skilled students: Evidence from a discontinuity. Journal of Labor Economics.

Card, David, and Alan B. Krueger. 2005. Would the elimination of affirmative action affect highly qualified minority applicants? Evidence from California and Texas. Industrial and Labor Relations Review 58, no. 3: 416-34.

Carrell, Scott E., and Bruce Sacerdote. 2013. Why do college going interventions work? NBER Working Paper no. 19031, National Bureau of Economic Research, Cambridge, MA. http://www.nber.org/papers /w19031.

Carruthers, Celeste K., and William F. Fox. 2016. Aid for all: College coaching, financial aid, and post-secondary persistence in Tennessee. Economics of Education Reviere 51, no. C: 97-112.

Castleman, Benjamin L., Lindsay C. Page, and Korynn Schooley. 2014. The forgotten summer: Does the offer of college counseling after high school mitigate summer melt among college-intending, low-income high school graduates? Lournal of Policy Analvsis and Management 33, no. 2:320-44. 
Cohodes, Sarah R., and Joshua S. Goodman. 2014. Merit aid, college quality, and college completion: Massachusetts' Adams scholarship as an inkind subsidy. American Economic Iournal: Applied Economics 6, no. 4: 251-85.

Dale, Stacy B., and Alan B. Krueger. 2014. Estimating the effects of college characteristics over the career using administrative earnings data. Lournal of Human Resources 49, no. 2:323-58.

Dillon, Eleanor Wiske, and Jeffrey Andrew Smith. 2013. The determinants of mismatch between students and colleges. NBER Working Paper no. 19286, National Bureau of Economic Research, Cambridge, MA. http://www.nber.org/papers/w19286.

Dynarski, Susan M., Steven W. Hemelt, and Joshua M. Hyman. 2015. The missing manual: Using National Student Clearinghouse data to track postsecondary outcomes. Educational Evaluation and Policy Analysis 37, no. 1 (suppl.):53S-S79.

Goodman, Joshua. 2008. Who merits financial aid? Massachusetts' Adams scholarship. Lournal of Public Economics 92, no. 10:2121-31.

Hastings, Justine S., Christopher A. Neilson, and Seth D. Zimmerman. 2013. Are some degrees worth more than others? Evidence from college admission cutoffs in Chile. NBER Working Paper no. 19241, National Bureau of Economic Research, Cambridge, MA. http://www.nber.org /papers/w19241.

Hoekstra, Mark. 2009. The effect of attending the flagship state university on earnings: A discontinuity-based approach. Review of Economics and Statistics 91, no. 4:717-24.

Hoxby, Caroline, and Christopher Avery. 2013. The missing “one-offs": The hidden supply of high-achieving, low-income students. Brookings Papers on Economic Activity, Spring, 1-50.

Hoxby, Caroline, and Sarah Turner. 2013. Expanding college opportunities for high-achieving, low income students. Discussion Paper 12-014, Stanford Institute for Economic Policy Research.

Hurwitz, Michael, and Jonathan Smith. 2016. Student responsiveness to earnings data in the College Scorecard. Working paper, SSRN: https:// papers.ssrn.com/sol3/papers2.cfm?abstract_id=2768157.

Imbens, Guido, and Karthik Kalyanaraman. 2012. Optimal bandwidth choice for the regression discontinuity estimator. Review of Economic Studies 79, no. 3:933-59.

Jepsen, Christopher, Peter Mueser, and Kenneth Troske. 2016. Labor market returns to the GED using regression discontinuity analysis. Lournal of Political Economy 124, no. 3:621-49.

Kaufmann, Katja Maria, Matthias Messner, and Alex Solis. 2013. Returns to elite higher education in the marriage market: Evidence from Chile. Working paper, SSRN: https://papers.ssrn.com/sol3/papers2.cfm?abstract _id=2313369. 
Lee, David S., and David Card. 2008. Regression discontinuity inference with specification error. Iournal of Econometrics 142, no. 2:655-74.

Leigh, Duane E., and Andrew M. Gill. 2003. Do community colleges really divert students from earning bachelor's degrees? Economics of Education Review 22, no. 1:23-30.

Long, Bridget Terry, and Michal Kurlaender. 2009. Do community colleges provide a viable pathway to a baccalaureate degree? Educational Evaluation and Policy Analysis 31, no. 1:30-53.

Long, Mark C. 2008. College quality and early adult outcomes. Economics of Education Review 27, no. 5:588-602.

McCrary, Justin. 2008. Manipulation of the running variable in the regression discontinuity design: A density test. Lournal of Econometrics 142, no. 2:698-714.

Pallais, Amanda. 2015. Small differences that matter: Mistakes in applying to college. Iournal of Labor Economics 33, no. 2:493-520.

Papay, John P., Richard J. Murnane, and John B. Willett. 2014. High school exit examinations and the schooling decisions of teenagers: Evidence from regression-discontinuity approaches. Lournal of Research on Educational Effectiveness 7, no. 1:1-27.

Pope, Devin, and Uri Simonsohn. 2011. Round numbers as goals: Evidence from baseball, SAT takers, and the lab. Psvchological Science 22, no. 1:71-79.

Reardon, Sean F., and Joseph P. Robinson. 2012. Regression discontinuity designs with multiple rating-score variables. Lournal of Research on Educational Effectiveness 5, no. 1:83-104.

Reynolds, C. Lockwood. 2012. Where to attend? Estimating the effects of beginning college at a two-year institution. Economics of Education Review 31, no. 4:345-62.

Rouse, Cecilia Elena. 1995. Democratization or diversion? The effect of community colleges on educational attainment. Iournal of Business and Economic Statistics 13, no. 2:217-24.

- 1998. Do two-year colleges increase overall educational attainment? Lournal of Policy Analvsis and Management 17, no. 4:595-620.

Saavedra, Juan E. 2008. The returns to college quality: A regression discontinuity analysis. Unpublished manuscript, University of Southern California.

Smith, Jonathan. 2013. Ova and out: Using twins to estimate the educational returns to attending a selective college. Economics of Education Review $36: 166-80$.

Smith, Jonathan, Michael Hurwitz, and Jessica Howell. 2015. Screening mechanisms and student responses in the college market. Economics of Education Review 44:17-28.

Smith, Jonathan, Matea Pender, and Jessica Howell. 2013. The full extent of student-college academic undermatch. Economics of Education Review 32:247-61. 
Smith, Jonathan, and Kevin Stange. 2015. A new measure of college quality to study the effects of college sector and peers on degree attainment. NBER Working Paper no. 21605, National Bureau of Economic Research, Cambridge, MA. http://www.nber.org/papers/w21605.

Vigdor, Jacob L., and Charles T. Clotfelter. 2003. Retaking the SAT. Iournal of Human Resources 38, no. 1:1-33.

White House. 2014. Increasing college opportunity for low-income students: Promising models and a call to action. Report, Executive Office of the President.

Zimmerman, Seth D. 2014. The returns to college admission for academically marginal students. Lournal of Labor Economics 32, no. 4:711-54. 